'A refreshing, eye-opening insight into gaining, growing and nurturing audiences for contemporary culture. As artists and arts organisations, too often we fall back on tempting people to attend who already know and love our artform. This study has thrown a light on a whole community that thrives on the new, the challenge, the experience of our boundary-breaking work. Understanding Audience Engagement in the Contemporary Arts demonstrates if we are bold, responsive and collaborative in our engagement with our cities, we will thrive alongside that community.

Everyone: every artist, every programmer, every curator, every marketing manager, every gallery assistant - and yes, every Executive Director - should read this book.'

- Seb Lovell-Huckle, Executive Director of Birmingham Contemporary Music Group, UK

'Stretching across disciplines, arts organisations and regions, the qualitative research insights in this book offer valuable new answers to some of the most urgent questions which preoccupy arts makers and their audiences today.'

- Helen Freshwater, Reader in Theatre \& Performance, Newcastle University, UK 
$\Longrightarrow$ Taylor \& Francis Taylor \& Francis Group http://taylorandfrancis.com 


\section{Understanding Audience Engagement in the Contemporary Arts}

Drawing on unique multi-arts, multi-city scholarly research, Understanding Audience Engagement in the Contemporary Arts makes a timely and urgent contribution to debates about the place of arts and culture in contemporary society.

The authors critically interrogate the challenges of access, diversity, privilege and responsibility in contemporary art. Asking who benefits from, pays for and consumes the arts, the book highlights fresh, forward-thinking audience and organisational attitudes that show the potential of live arts engagement to contribute to engaged citizenship. Complemented by comparative global analysis, the cutting-edge insights in this book are relevant for interdisciplinary researchers across audience studies and beyond.

Enhanced by a new framework for the understanding of audience engagement, the book is relevant to scholars, policymakers and reflective practitioners across the spectrum of arts and cultural industries management.

Stephanie E. Pitts is a professor of music education at the University of Sheffield. Her research and teaching interests are in musical participation, concert audiences and music education and in the qualitative research methods used to understand people's uses of music in their everyday lives.

Sarah M. Price is an audience researcher and member of the Sheffield Performer and Audience Research Centre (SPARC). As both an academic and a freelance audience researcher, Sarah has conducted audience research projects collaboratively with numerous arts organisations, including a Collaborative Doctoral Award with the City of Birmingham Symphony Orchestra. Her research interests are in the value of arts engagement, understanding audience behaviour and patterns of attendance, and the role of academic research within the arts industry. 


\section{Routledge Research in the Creative and Cultural Industries}

Series Editor: Ruth Rentschler

This series brings together book-length original research in cultural and creative industries from a range of perspectives. Charting developments in contemporary cultural and creative industries thinking around the world, the series aims to shape the research agenda to reflect the expanding significance of the creative sector in a globalised world.

Published titles in this series include:

\section{Arts and Business}

Building a Common Ground for Understanding Society, 1st Edition

Edited by Elena Raviola \& Peter Zackariasson

\section{Performing Arts Center Management}

Edited by Patricia Dewey Lambert \& Robyn Williams

\section{Arts and Cultural Management}

Sense and Sensibilities in the State of the Field

Edited by Constance DeVereaux

Managing Organisational Success in the Arts

Edited by David Stevenson

\section{Music Business Careers}

Career Duality in the Creative Industries

Cheryl Slay Carr

Racial and Ethnic Diversity in the Performing Arts Workforce Tobie S. Stein

Understanding Audience Engagement in the Contemporary Arts Stephanie E. Pitts and Sarah M. Price

Access, Diversity, Equity and Inclusion in Cultural Organizations Insights from the Careers of Executive Opera Managers of Color in the US Antonio C. Cuyler

For more information about the series, please visit www.routledge.com/ 


\section{Understanding Audience Engagement in the Contemporary Arts}

Stephanie E. Pitts and Sarah M. Price 
First published 2021

by Routledge

2 Park Square, Milton Park, Abingdon, Oxon OX14 4RN

and by Routledge

52 Vanderbilt Avenue, New York, NY 10017

Routledge is an imprint of the Taylor E Francis Group, an informa business

(C) 2021 Stephanie E. Pitts and Sarah M. Price

The right of Stephanie E. Pitts and Sarah M. Price to be identified as authors of this work has been asserted by them in accordance with sections 77 and 78 of the Copyright, Designs and Patents Act 1988.

With the exception of Chapter 7, no part of this book may be reprinted or reproduced or utilised in any form or by any electronic, mechanical, or other means, now known or hereafter invented, including photocopying and recording, or in any information storage or retrieval system, without permission in writing from the publishers

Chapter 7 of this book is available for free in PDF format as Open Access from the individual product page at www.routledge.com. It has been made available under a Creative Commons Attribution-Non Commercial-No Derivatives 4.0 license.

Trademark notice: Product or corporate names may be trademarks or registered trademarks, and are used only for identification and explanation without intent to infringe.

British Library Cataloguing-in-Publication Data

A catalogue record for this book is available from the British Library

Library of Congress Cataloging-in-Publication Data

A catalog record for this book has been requested

ISBN: 978-0-367-35888-4 (hbk)

ISBN: 978-0-429-34245-5 (ebk)

Typeset in Bembo

by Apex CoVantage, LLC

All illustrations by Beka Haigh

bekahaytch.wordpress.com

(a)beka_haytch 


\section{Contents}

List of tables $\quad$ ix

Acknowledgements $\quad \mathrm{x}$

Foreword xii

1 Introduction: who goes to the contemporary arts? 1

2 Understanding audiences: research methods and approaches

3 'But is it art?': defining the contemporary arts 35

4 Cities for the arts: the importance of place in audience engagement

5 Art forms, venues and audience decision-making: navigating the cultural ecology

6 Routes to engagement in the contemporary arts

7 'It's okay not to like it': the appeal and frustrations of the contemporary arts

8 Making sense of the contemporary arts: programme notes, gallery panels and arts talk

9 Uncomfortable questions in contemporary arts practice and research: the formaldehyde shark in the room

10 Audience development and the future of the contemporary arts: learning from audiences 
viii Contents

Appendix A: life-history interview schedule from pilot study

Appendix B: interview schedule from the national study

Appendix C: national survey

Index 


\section{Tables}

2.1 Partner organisations 20

2.2 Demographics of participants in the pilot phase (Birmingham, 2014-15)

2.3 Demographics of participants in the national phase (2017-18) 22

3.1 Responses to the National Survey defining 'contemporary' 41 


\section{Acknowledgements}

The three years that have gone into making this book have been a turbulent time to be British, as the Brexit referendum and two general elections have seen the country become an angrier and more divided place. In academia too, the multitude of conflicting pressures and measures have sometimes left us feeling disillusioned and therefore even more grateful for the colleagues and friends who have kept us inspired and grounded throughout the Understanding Audiences for the Contemporary Arts (UACA) project.

A research project of this scope would never have been possible without the help of our research support officer, Elizabeth Dobson; we would like to thank her for navigating impenetrable finance systems and for her inspired event planning. We would like to thank our coinvestigator, Helen Freshwater, for offering wise words and encouragement at key moments; also Jonathan Gross and Tim Rushby, for their work on the pilot, and Seb Lovell-Huckle for taking on the national study. Thanks also to colleagues from Sheffield and farther afield: Fay Hield, Matt Jones, Amy Ryall and the many inspiring researchers we have met at conferences in Maastricht, Belgrade, Berlin, Leeds, York and above all at the first Audience Research in the Arts conference in Sheffield.

Stephanie would like to thank loyal friends for providing constant support and welcome distractions: Karen, Rich, Oscar and Issy, for sharing holidays and stand-up comedy; Susan for her distinctive theatre-booking system, sadly not mentioned in any of the interviews; Norman, Sue and Anne, for walks enjoyed across Yorkshire and Derbyshire, with the promise of now saying yes more often; Matthew and Glossop Choral Society, for keeping me making music; and, as always, my parents for filling my childhood bookshelves and now keeping space on theirs for my own efforts.

Sarah would like to thank Mom and Dad, for years of taxis to and from rehearsals; Bec and Bob, for home-cooked meals and cups of tea; Sophie, for endless smiles and silliness; friends who were there from the start and those who have joined along the way: Sarah, Mike, Jon, Jen and Sophie; and to Seb, for coming along on this journey for the third time.

We are grateful to the Arts and Humanities Research Council for funding such an ambitious project and to Routledge for their interest in this topic and their flexible deadlines. Thanks also to Beka Haigh for the fresh perspectives 
provided by her illustrations for the book and her visual minutes at our Open Space event.

We would like to thank the many arts organisations who have been involved in this project, from the 20 official partners to the many more whose insights have shaped this research in unseen ways. Finally, we are very grateful to all the participants who gave up their time so generously to take part; their openness and honesty has made this one of the sweariest academic books we know, and we wouldn't want it any other way. 


\section{Foreword}

I'm very proud to have been a member of the Understanding Audiences for the Contemporary Arts team. In what follows, you'll read the background, methodology and findings for what we believe to be the largest qualitative study of contemporary arts audiences in the UK to date. Stretching across disciplines, a wide range of arts organisations, and four cities, this study draws out the insights provided by 187 individual interviews and the detail of over 1.5 million words. This scope enables the offering of valuable new answers to some of the most urgent questions which preoccupy arts makers and their audiences today.

As Co-Investigator on this project my role has primarily been advisory. Occasionally I've been up close to some of the key decisions, and in the room with representatives from the arts organisations involved. I've had the pleasure of listening to interview recordings and discussing the transcripts with Sarah and Stephanie. But mostly I've been working at a distance, offering what I hope was a useful sounding board as they negotiated the inevitable challenges that a project of this scope was bound to generate. In the book that follows, much of the time and effort involved in setting up, managing and carrying out a project on this scale will be hidden. The professional and emotional labour put into developing - and maintaining - good relationships with all the arts organisations involved will be only implicit, though it was central to the success of the project. The challenge of recruiting interviewees is in the description of the project's methodology, but not the amount of time Sarah spent on trains between Liverpool, Bristol, Birmingham, Sheffield and London, or the days when one or more of the interviewees lined up cancelled on her. The energy and skill required to get the most out of these interviews when they did take place will also be underplayed: the balance needed between setting someone at their ease and maintaining an appropriately professional distance; the skill of responsive listening which draws out revealing detail whilst also keeping the interview on track and on time.

Listening to the recordings of numerous interviews enabled by this labour brought many of these aspects of the project to the fore. On the page, you lose the texture of the context in which these exchanges took place: the clatter of coffee cups; scraping of chairs; banging doors. Similarly, it's impossible to 
capture the specificities of each exchange here: accent, affect and tone drop away as the words lying before you invite you to concentrate upon what is said, rather than how. But listening to some of those recordings, it was easy to feel myself positioned as fascinated eavesdropper upon a meeting between strangers, noting the quality of each hesitation, laugh, and reflective pause as I attended to someone working through their artistic attachments and compulsions, their memories and sense of self. This listener also got a sense of the pleasures involved in these acts of attention and dialogue. Certainly, the interviewees' willingness to contribute their time, experience and insights to the project serves to highlight the satisfaction involved in being asked - and of being told, as a member of the audience, that our opinions matter. The conversations which followed after the microphone was switched off also lie beyond the reach of this book, but Sarah reported that interviewees had numerous questions for her at this point. These questions reflected interviewees' curiosity about the project as a whole, as they asked about the ultimate destination for their thoughts, and the details of their enthusiasms and frustrations with the contemporary arts. Of course, the analysis that follows scrupulously protects the anonymity of the participants, but it also engages with the complexities of their individual responses, and privileges their words.

The Understanding Audiences for the Contemporary Arts project has a life beyond and after this book: the project's sector handbook, aimed at arts practitioners and organisations, encapsulates many of its findings in a different form, and can be found on the Sheffield Performer and Audience Centre website. Stephanie and Sarah have shared the project's findings at conferences and symposia over its duration, including a large international conference in Sheffield in July 2019 , organised as part of the project. The scholars and practitioners gathered at this event generated further questions for us all, as we contemplated the audience for audience research. How do academics effectively communicate their research insights to policy makers and the sector? How do we get our knowledge and understanding heard and acted upon? Readers of this book members of the audience for audience research - will probably all have thoughts on the answers to these questions. But the research carried out and analysed here makes me more convinced than ever of the importance and significance of qualitative research. We need to be able to put flesh on the bones of the figures - to be able to describe lives and experiences, to cite individual testimonials and take-downs. We need to hear voices speaking - not only about impacts felt or unfelt; and meanings made or unmade - but also about experiences of inclusion or exclusion, about being an audience for some pieces of art work but not of others, about being made to feel welcome in some places and not in others. This book invites its readers to recognise the challenges of enabling this kind of listening, in order to truly grasp what is involved in understanding audiences.

Helen Freshwater, Newcastle University 


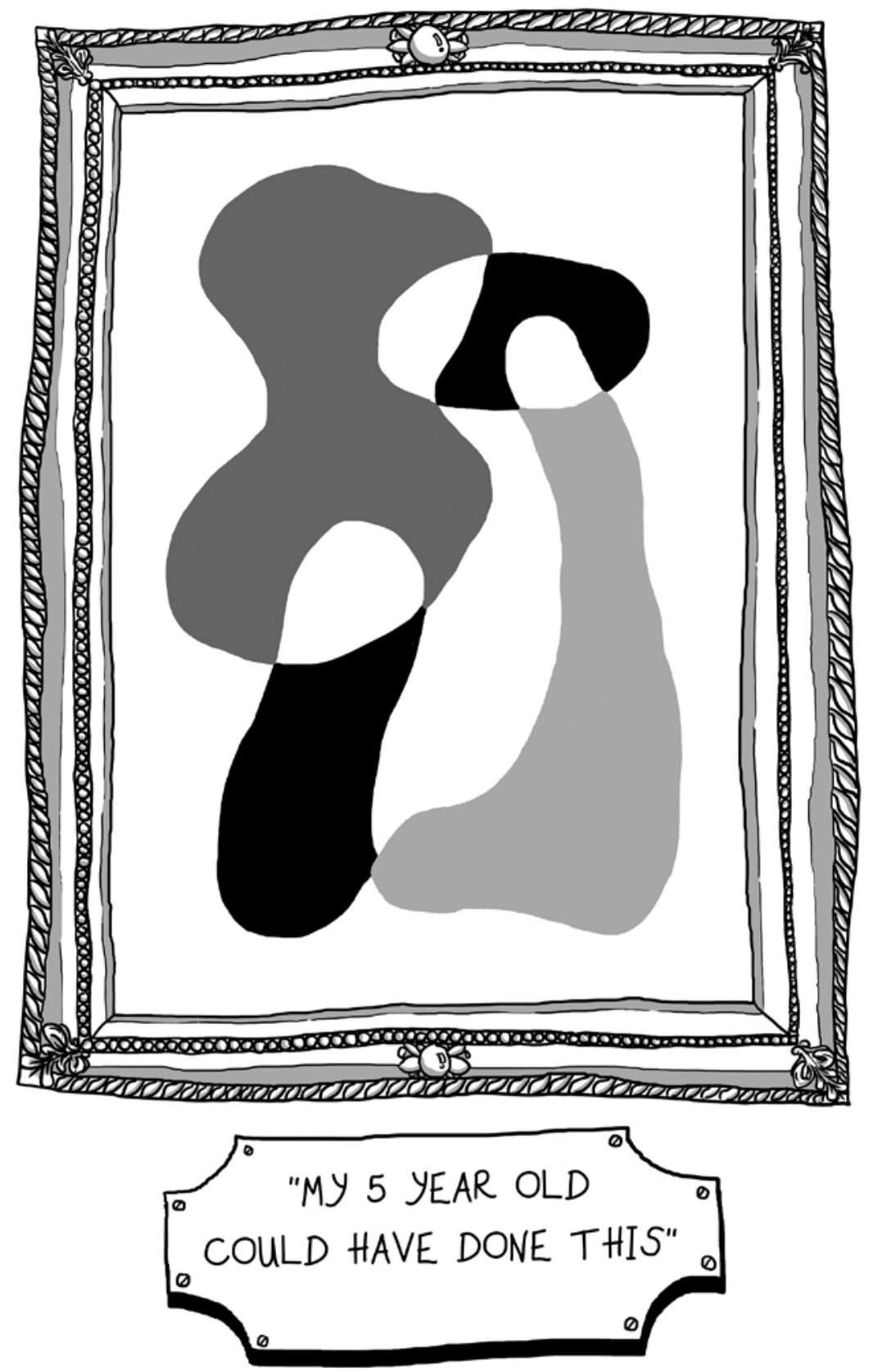




\section{Introduction}

\section{Who goes to the contemporary arts?}

'Contemporary art' is something of a contentious term. In the clichéd response to contemporary visual art, 'My five-year-old could have done that', there are connotations of simplicity, lack of perceivable skill and a fear of being taken for a fool. The Turner Prize, an annual award for British contemporary visual art, is a flashpoint for these negative stereotypes and attracts journalistic criticism (e.g. Reynolds, 2001) for works that are perceived to be weird, experimental, pretentious and without skill. A YouGov poll (2016) of 4,099 British adults found that only $28 \%$ considered $A$ Fun Ride to Nowhere, an artwork in Josephine Pryde's Turner Prize 2016 Runner-Up exhibition, to be a work of art (see also Smith, 2016). This survey additionally showed that broader, more inclusive definitions of art came from younger participants, those who were middle class, those in London and the South and those who voted to remain in the European Union. Attitudes to the arts are brokered along social divisions and reinforced by newspaper and social media choices to create both awareness and anger about the place of contemporary arts in modern society.

These stereotypes around the contemporary arts have proliferated popular culture as well. In internet culture, memes mocking contemporary arts have also emerged, such as the photo of a squirrel seemingly dancing, with the words 'People will stop asking you questions if you answer back in interpretive dance'. In a spoof of the old-fashioned Ladybird children's books, Miriam Elia produced the sell-out We Go to the Gallery (2015), a satire of contemporary art galleries, in which a mother enjoys interpreting strange contemporary artworks, while the two children are just confused and unsettled. This story was mirrored in real life by two American teenagers who left glasses on the floor of an art gallery and then documented tourists taking photos of the 'exhibition', striking a chord amongst those who enjoyed seeing gallery visitors being fooled such as in this comment below a Guardian (Hunt, 2016) article about the story: 'I wonder how many stood round, viewed them from different angles and then spouted a load of arty farty nonsense in a language only they understand.' If there was any doubt as to whether these stereotypes persist, in the final stages of writing this book, the piece Comedian by Maurizio Cattelan consisting of a fresh banana taped to a wall caused public outrage when it sold for $\$ 120,000$ (Ilchi, 2019).

Mockery of contemporary theatre and dance is also found in popular culture, with American sitcoms such as How I Met Your Mother and Community including 


\section{Introduction}

episodes in which characters take part in weird and somewhat self-indulgent community drama and dance performances (Bays, Thomas, Kang, \& Kellett, 2007; Harmon, Pomerantz, \& Cackowski, 2010). In an episode of US sitcom Modern Family, the character Mitchell Pritchett is hoodwinked into attending an immersive theatre performance, which he describes as 'the worst thing that can happen to a human during peace time' (Levitan, Lloyd, Richman, \& Walls, 2016, 0:04:50). Meanwhile, contemporary music is acknowledged as being something that even most audience members dislike, with Alex Ross (2010, 2007) lamenting the lack of cultural champions who might embrace new music in the same way that modern architecture and visual art are publicly defended.

These stereotypes around the contemporary arts in the UK are part of the context for this book, prompting us to ask how audience experience challenges and is challenged by these negative tropes. How does the public discourse impact on audience members' willingness to engage with the contemporary and shape their experience of an artwork? How is it that some people find joy in new artworks? What are the routes that take them past stereotypes to meaningful engagement, and are these routes open to everyone? Who is and who is not engaging with the contemporary arts?

\subsection{What is the 'contemporary' and who engages with it?}

To explore this question of who forms the audience for the contemporary arts, we first had to grapple with what was meant by 'contemporary'. This word was adopted for the project by default since it appears in the name of our first collaborating arts organisation, Birmingham Contemporary Music Group (see Section 2.2.1), but has been problematised throughout. In the broadest sense, any art made today could be termed 'contemporary', but this did not seem like a meaningful definition, since it put highly commercial and popular artists in the same category as experimental and underground artists, so blurring the distinctions between the radically different funding structures, media prominence and venues that are part of the varied audience experience across recently made artworks. We therefore provisionally defined 'contemporary' as artworks which were both new and, in some way, innovative or challenging. This definition is, of course, highly subjective, and the personal way in which the contemporary is felt and experienced will be a running theme of this book. Indeed, while systems such as the Audience Agency's art form coding call on arts organisations to 'tag' their events as contemporary, modern or other such categories within each art form, this does not necessarily map onto how the work is experienced by its audiences. ${ }^{2}$

Contemporary arts audiences are generally assumed to be small in number, well-educated and highly engaged arts consumers. However, the available audience attendance data gives a more complex picture. Audience Agency's (Bradley, 2017) analysis of classical music subgenres suggests that contemporary classical music averages 111 attenders per concert, which is middle of the range between orchestral concerts (average 336) and community events (average 
68). Their analysis points to these contemporary attenders being younger and more urban but does not suggest a particularly small audience for these events. Taking Part Survey (2016) data on dance audiences suggests that a slightly smaller proportion of the UK population attends contemporary dance $(3.1 \%$ had attended in the past 12 months) than ballet (4.2\%) and that contemporary dance attenders were also younger; however, Hanquinet, O'Brien, and Taylor's (2019) analysis found contemporary dance to be less socially stratified than ballet. Furthermore, the UK bastion of contemporary art, the Tate Modern, is the country's most visited attraction, with almost 6 million visits in 2018 (Visit England, 2019). The scarcity of audience attendance data that is broken down into contemporary and classical means it is difficult to conclude beyond observations and hunches that the contemporary arts attracts a smaller and more affluent audience, and these data often do not capture grassroots or DIY (from 'do it yourself') events, leaving many smaller events undocumented.

This project comes at a time of intense debate about the future of governmental arts funding in the UK and abroad. Recent policy developments have seen an increased focus on funding being used to broaden access to the arts, with the diversification of artists, arts workers and audiences being a key requirement for public funds. Furthermore, with recent initiatives such as 64 Million Artists, ${ }^{3}$ Fun Palaces, ${ }^{4}$ Creative People and Places ${ }^{5}$ and ongoing research into everyday participation $^{6}$ and cultural democracy (Wilson, Gross, \& Bull, 2017), the trend is very much towards work that is produced and programmed by local communities, in which diverse voices are heard and the right to creative practice is shared beyond professional artists. Attempts to open up access to the arts are to be lauded, though researchers have rightfully problematised the co-opting of arts to achieve social policy goals (Belfiore \& Bennett, 2007). However, against this changing funding climate, it is becoming harder to justify the use of funding for events which are believed to attract an affluent and niche audience and are assumed to overlook the needs of the wider population.

The contemporary arts therefore act as a microcosm in which to investigate the arts sector today, raising challenging questions about the value of certain artworks over others and questioning the future direction of arts production in the UK. The contemporary arts organisations that we have collaborated with in this project (see Section 2.2.1) have often reluctantly been the 'small fry' in their city's arts scene, with audience numbers, size of organisation or proportion of programming meaning that their role in the arts ecosystem is frequently overlooked, despite representing the cutting edge and, in theory, the future of each art form. Working collectively, across art forms and cities, has helped to identify the common challenges facing small arts organisations and so to articulate the contribution of contemporary arts to the provision of diverse and inclusive arts experiences.

This book aims to shine a spotlight on the contemporary arts in the UK today through the eyes of its audiences. We wrestle with the difficult questions around stereotypes of the contemporary, exclusion and access and the ways in which people feel shut out of the arts. However, we also reflect on the ways in which audiences find meaning in new work, considering how they find a 


\section{Introduction}

way to engage with it, what kinds of attitudes they take to their arts events and the value they find in work that others may see as unskilled or alienating. In considering the idea of the contemporary in multiple art forms, we explore the ways in which audiences navigate the cultural ecology of their local area, and whether or not there is such a thing as a 'contemporary audience'.

\subsection{Origins}

This project began as the unexpected outcome of a research seminar given in Birmingham in 2013 by Stephanie Pitts. After hearing her account of previous studies with audiences for classical music, Tim Rushby, then the marketing manager at Birmingham Contemporary Music Group (BCMG), posed the challenge of understanding how audiences for contemporary music might be different. Specifically, Tim wanted to know whether there was crossover in audiences for contemporary arts: might visitors to the Ikon Gallery in Birmingham, just down the road from where BCMG gives its concerts, also be potential audience members? Likewise, might the audiences for the BE Festival, an international contemporary theatre programme in the city, also be attending BCMG concerts, without either organisation being aware of the intersecting cultural lives of their regular attenders? From these questions about attendance patterns came deeper provocations: did audiences seek comparable experiences of new work in multiple art forms, and could there possibly be a 'contemporary arts audience', a group of people who sought out the new in art regardless of form or style?

Faced with these intriguing questions, the Sheffield Performer and Audience Research Centre (SPARC) team conducted a pilot study in Birmingham (2014-15), supported by the University of Sheffield's Innovation, Impact and Knowledge Exchange fund. Led by Stephanie Pitts, Tim Rushby and research associate Jonathan Gross, a group of organisations who present contemporary art in the city were brought together to discuss the most pertinent themes for their organisation. This fledgling meeting of what later became Birmingham Contemporary Arts Network (BCAN) discussed the ways in which their challenge of 'selling' contemporary arts to audiences was considerably different to that of organisations producing classical or mainstream events, since the general public was often taught by the media that contemporary arts were pretentious and 'rubbish'. They had also found that audiences tended to dismiss contemporary arts after one bad experience in a way that does not happen with film, for example, where one disappointing night out is quickly superseded by other more satisfying cinema experiences. Organisations were looking to learn more about what draws people to the contemporary and what puts people off in order to grow and diversify their current audiences.

The pilot study therefore focused on the following questions:

- Who is coming to the contemporary arts - and what experiences are they having of this work? 
- What value do the contemporary arts have for audiences?

- What strategies are contemporary arts organisations currently employing to develop relationships with audiences - and what strategies might they employ in the future?

Qualitative research methods were employed in the pilot study for a number of reasons (outlined in full in Chapter 2). From the outset, we were seeking to understand engagement in contemporary arts from the audience's point of view, embracing the ideas of challenge and difficulty identified in the public discourse and the experience of our partner organisations but then investigating how these were overcome or even enjoyed by highly engaged attenders. Our partner organisations, selected to reflect a range of organisation size, venue use and programming, helped us to recruit 57 audience members who were interviewed about their current arts engagement and the life histories that had shaped their cultural activities and perspectives.

The pilot study data generated new insights on the facilitative conditions and attitudes that encourage audiences to take risks on untried and untested works: these were reported in interim publications from the study (Gross \& Pitts, 2015, 2016) and fed back to our partner organisations in Birmingham. Inevitably, the process of analysing those rich, qualitative accounts served to further complicate Tim Rushby's initially straightforward questions, so increasing our appetite for a national phase of research that would set our pilot study findings in a broader context through some more ambitious questions:

- Are the strong civic pride and identity expressed in Birmingham (and in Sheffield in previous studies) similar in other cities?

- Are routes into contemporary arts similar across art forms? What are the expectations and experiences that audiences bring to their contemporary arts engagement?

- How can arts organisations work together to implement and respond to our findings? How do the in-depth audience views we have gathered chime with or challenge institutional perspectives?

- What do we learn about arts education, arts marketing, arts consumption and arts engagement from rich, qualitative data?

Following a successful funding application to the Arts and Humanities Research Council (AHRC), a 30-month national project titled 'Understanding Audiences for the Contemporary Arts' was launched in May 2017, taking these insights and unanswered questions to three new UK cities: Bristol, Liverpool and London.

The decision was taken to base the project in large metropolitan areas because the pilot study had highlighted how much the decision to attend is influenced by the amount and diversity of arts events on offer, and we were interested to explore this in additional cities to strengthen those conclusions. Exploring the experience of rural arts attenders would undoubtedly be different, and while these differences surfaced in some interviews with participants who had 


\section{Introduction}

previously lived outside the cities where we did our research, this remains a topic for future investigation (see Kawashima, 2000).

These particular three cities were chosen to offer contrast with our Birmingham findings and with previous research in Sheffield (Pitts, 2005, 2016; Pitts \& Spencer, 2008): we looked for locations that were geographically distinctive from those two inland, post-industrial cities and that offered diversity in the demographics and transience of the population. These factors were relevant to our participants' experiences and our analysis: both Birmingham and Bristol have high levels of incoming population from London (Bristol City Council, 2019, p. 15; Jones, 2019), for example, and our participants in Bristol showed strong connections with the capital city in their arts attendance and expectations (see Section 4.3). The size of the Black and Minority Ethnic (BAME) population was markedly different across the cities, with over 40\% BAME population in Birmingham and London, 16\% in Bristol and only 14\% in Liverpool (Birmingham City Council, 2013, p. 15; Bristol City Council, 2019, p. 25; Liverpool City Council, 2013; Gov.uk, 2018), meaning that discussions of diversity and inclusion were often shaped by experiences of standing out in a majority white audience (see Section 9.1.2). All four cities had large student populations, but Bristol was notable for its underrepresentation of over-65s (12.9\% compared to $18.5 \%$ in England and Wales; Bristol City Council, 2019, p. 5), which could be one driver for the youthoriented festival culture noted by many residents (see Section 4.1.2).

We were also guided by the suitability of available partners, seeking a strong contemporary arts provider in each city to be our lead partner organisation and to provide us with a spread of art forms across the project: Spike Island in Bristol, Bluecoat in Liverpool and Bush Theatre in London. The decision to include London was a consciously problematic one: London is undoubtedly different to all other UK cities in its size, the density and diversity of its population and the extent of its arts provision. We knew that we would not be able to gain the citywide perspective that we sought in the three other sites of research but felt that understanding those differences was important to the project and that not to include London would be too obvious an omission. As the research unfolded, investigating how London was different gave a valuable framework for contrasting the provision in other cities and for highlighting the place-specificity of audience experience (see Section 4.2).

From simple beginnings, therefore, our project Understanding Audiences for the Contemporary Arts (UACA) became a multi-location, multi-art form investigation - to our knowledge, the largest qualitative study of contemporary arts audiences in the UK. This book is heavily rooted in the data from the study, since gathering audience perspectives in that depth and on that scale has been a rare opportunity, worthy of thorough analysis and detailed presentation in order to be of the greatest use to the kinds of organisations and audiences that we encountered. In the same way that Tim Rushby's initially simple question led us to increasingly provocative debates, we have found that understanding audiences for the contemporary arts is a route into tackling some of the most pressing and challenging questions in culture and society today: who gets to make art, who is it for, and what is its purpose? 


\subsection{Overview}

Following a detailed account of our methods in Chapter 2, this book is structured thematically into eight chapters. In Chapter 3, we begin our analysis and discussion as we began the project, by exploring definitions, boundaries and crossovers in the contemporary arts. We demonstrate the ways in which the term 'contemporary' is understood by different participants and explore how it is used and what it signifies in relation to the arts and their consumption. Drawing on the responses of nonattenders, which are often neglected in the research literature, we expose some of the stereotypes of different art forms and the ways that they play into risk aversion in potential audiences: the fear of being expected to join in at contemporary theatre, for example, or the sense that modern art and music are pretentious, can lead people to avoid an unfamiliar art form or dismiss it after one experience. We analyse the various contemporary arts stereotypes that are still present amongst even the most engaged attenders to draw out common themes that provoke hostile reactions in audiences and in public discourse.

Having briefly introduced our research locations earlier, Chapter 4 considers the way in which cities shape and dictate audience members' engagement. The rare opportunity to compare audience decision-making and attendance habits in four UK cities enables our research to explore the sense of civic engagement which had emerged in our pilot study as a strong factor in supporting local arts venues (Gross \& Pitts, 2016). Each of the regional cities had a sense of its own uniqueness: for Liverpool, this was founded on the legacy of the City of Culture 2008; for Bristol, a sense of 'the Bristol experience' of young professionals; and for Birmingham, a desire to support arts organisations' resilience in the face of declining funding. The question 'How is your city as a place for the arts?' was met with detailed and sometimes defensive responses everywhere except London, where the sense of being theoretically able to do anything (but practically limited in making those choices) was stronger. Through our analysis of how people navigate the arts differently in London, we pose a challenge to audience research that assumes all attendance to be place neutral and argue for a stronger consideration of civic engagement and local pride in audience development. Additional light is shed on the importance of locality through a consideration of tourism and mobility in each city, exploring the 'hometown', 'newcomer' and 'visitor' mindsets and the ways in which organisations address each of those. In order that the research approaches we have taken could be applied in other cities to further understand the place-specificity of audience experience, our two interview schedules and national survey are provided as appendices.

Chapter 5 dwells on one of the unique aspects of this project - that is, the rich, qualitative descriptions of how audiences interact with multiple art forms. We explore the distinctiveness of audience decision-making and experiences in music, dance, drama and visual arts and consider the presentational rituals that make some art forms less accessible than others, comparing the ease of dropping into a gallery with the assumption that prior knowledge is needed to enjoy a contemporary music concert. We then move on to discuss the ways in which 


\section{Introduction}

venue shapes experience, opening up or closing off events to different types of audiences. Several of our venue-based partners offer an accessible space to the public - a garden, cafe or bar that has its own loyal clientele who are made welcome in the venue without necessarily connecting with the art that is made or presented there (e.g. Bluecoat, Liverpool; The Albany, London). We have come to think of these as liminal social spaces, which draw people into some venues and risk keeping them away from others. We use these findings to propose a new framework for understanding how venues can enhance or detract from an arts event and the privilege at play in moments where they go unnoticed.

While research with classical music audiences regularly reports concerns about how concert attendance habits are no longer being formed in schools and homes (Kolb, 2001; Johnson, 2002), in Chapter 6 we show that routes into contemporary arts appear to be more flexible and serendipitous. We will examine the open-mindedness that brings people to contemporary arts through interest in the subject matter, support for a venue or shared interests with friends but also the limits of that open-mindedness, which causes even the most ardently experimental audience member to 'try anything, but not that'. The multi-arts nature of our project means that we can explore patterns across art forms: what does 'being a contemporary theatre person', for example, mean to those who embrace that identity - and to those who do not? We look at how audience members characterise their own behaviour as being sociable or self-sufficient, frequent or occasional, fully engaged or on the periphery, eclectic or specialist and consider what those behaviours and beliefs mean for the promotion of contemporary arts events.

Having examined routes into contemporary arts attendance, the focus in Chapter 7 is on the experiences of attenders, and the ways in which they approach unfamiliar and sometimes challenging works and events. Whereas the idea of a 'guaranteed good night out' has been strong in other audience research (e.g. Pitts, 2016), contemporary arts audiences were able to find pleasure in the process of grappling with works they had not enjoyed or understood. They articulated a broader cultural responsibility to support the creation of new art and the survival of under-funded, niche organisations, sometimes demonstrating this support through offering volunteer help and financial support. Even the most die-hard enthusiasts had their limits, however, and were alert to perceived cynicism or inauthenticity on the part of audiences or promoters. There were also facilitative conditions that increased the likelihood of repeat, open-minded attendance, including promotion of free events; recommendations from trusted sources; and access to backstage, 'work in progress' insights.

A strong feature of our audience interviews was the struggle that respondents had to describe both the arts that they love and those that would habitually avoid. Their answers were heavily laden with moral and aesthetic judgements about things that they 'should' do as well as reflections on the difficulty of explaining their pleasure in contemporary arts to friends who do not attend. Chapter 8 draws upon our interviews and the responses to our national survey, and here we explore the language that is meaningful to a wide range of arts audience and the ways that marketing images and text speak to them (or not). Our conversations with arts marketers have also explored the challenges 
of describing an as yet unknown (or unmade) work in ways that will attract an audience and of supporting events and exhibitions with commentary that enhances rather than disrupts the experience. We found that conversations about contemporary arts can be part of the sense-making for audiences, and in many ways liberating, since everyone can be assumed to be equally unfamiliar with the work and therefore able to make a personal response. This discovery offers a new way in to supporting the arts talk (Conner, 2013), audience exchange (Pitts \& Gross, 2017) and post-show discussions (Dobson \& Sloboda, 2014) that have become a growing feature of arts presentation, by creating conditions in which prior knowledge is articulated but not assumed and emotional responses are valued as a form of understanding.

At various stages in this project, we have encountered the challenges and criticisms that routinely face arts organisations: what is the place of the contemporary arts in society, does it make sense to support art forms that routinely reach only a small and privileged section of the population and to what (arguably limited) extent do the production of and audiences for contemporary arts reflect the diversity of today's society? We took care to gather the views of engaged arts attenders who would not choose the contemporary as part of their cultural diet and to examine the strength of feeling expressed in antagonism to the funding of contemporary arts in the popular press. We consider where the contemporary arts sits within a climate of declining funding for large venues and for arts education and what lessons there are to be learned from the open-mindedness of enthusiasts for the contemporary arts, who seek to be challenged rather than comforted by their encounters with live performance.

In Chapter 9, we grapple with the difficult questions of inequality and quality in the contemporary arts, highlighting the privilege at work in being able to both present and engage with experimental work. Equipped with in-depth analysis of how audiences approach (or avoid) the contemporary arts, we conclude the book with a discussion in Chapter 10 of what this insight means for artists, organisations and audiences of the future. We reflect on audience members' resistance to being 'developed', with many being perfectly content with the frequency and nature of their arts engagement. We also propose that the ways in which contemporary arts audiences find their satisfaction and pleasure have valuable messages for all kinds of arts engagement: understanding that a response to live art can be uncertain, changing and personal is an attitude often lost in the presentation of established repertoire and becomes a source of frustration or alienation for new attenders. Finally, we reflect on the networks of arts organisations that have built up in our four fieldwork cities and on the benefits and challenges of collaborative working in a sector which has more to gain from sharing audiences than competing for them.

\section{Notes}

1 https://me.me/i/people-will-stop-asking-you-questions-if-you-answer-back-2498153

2 'All you need to know to complete your Artform Coding', www.theaudienceagency.org/ resources/artform-coding 
3 https://64millionartists.com/

4 http://funpalaces.co.uk/

5 www.creativepeopleplaces.org.uk/

6 www.everydayparticipation.org/

\section{References}

Bays, C. (Creator), Thomas, C. (Creator), Kang, K. (Writer), \& Kellett, G. C. (Executive story editor). (2007). Stuff [Television series episode]. In C. Thomas (Executive producer), How I met your Mother. Beverly Hills, CA: CBS Broadcasting.

Belfiore, E., \& Bennett, O. (2007). Determinants of impact: Towards a better understanding of encounters with the arts. Cultural Trends, 16, 225-275. doi:10.1080/09548960701479417

Birmingham City Council. (2013). 2011 census: Birmingham population and migration topic report. Retrieved from www.birmingham.gov.uk/downloads/file/4564/2011_census_ birmingham_population_and_migration_reportpdf

Bradley, C. (2017). National classical music audiences: An analysis of audience finder box office data for classical music events 2014-2016. Retrieved from www.theaudienceagency.org/asset/1303

Bristol City Council. (2019). The population of Bristol November 2019. Retrieved from www. bristol.gov.uk/documents/20182/33904/Population+of+Bristol+November+2019. pdf/51bd3d27-b720-0948-6157-620a51a50f6a

Conner, L. (2013). Audience engagement and the role of arts talk in the digital Era. New York: Palgrave Macmillan.

Dobson, M. C., \& Sloboda, J. (2014). Staying behind: Explorations in post-performance musician-audience dialogue. In K. Burland \& S. E. Pitts (Eds.), Coughing and clapping: Investigating audience experience (pp. 159-173). Farnham: Ashgate Publishing.

Elia, M. (2015). We go to the gallery: A dung beetle learning guide. Dunging: Dung Beetle Ltd.

Gov.uk. (2018). Regional ethnic diversity. Retrieved from www.ethnicity-facts-figures.service. gov.uk/uk-population-by-ethnicity/national-and-regional-populations/regionalethnic-diversity/latest

Gross, J., \& Pitts, S. (2015). Understanding audiences for the contemporary arts. Retrieved from www.sparc.dept.shef.ac.uk/wp-content/uploads/2017/06/GrossPitts-June-2015REPORT-UNDERSTANDING-AUDIENCES-FOR-THE-CONTEMPORARYARTS-1-5.pdf

Gross, J., \& Pitts, S. (2016). Audiences for the contemporary arts: Exploring varieties of participation across art forms in Birmingham, UK. Participations: Journal of Audience $\mathcal{E}$ Reception Studies, 13(1), 4-23. Retrieved from www.participations.org/Volume\%2013/ Issue $\% 201 / 2$.pdf

Hanquinet, L., O’Brien, D., \& Taylor, M. (2019). The coming crisis of cultural engagement? Measurement, methods, and the nuances of niche activities. Cultural Trends, 2, 198-219. doi:10.1080/09548963.2019.1617941

Harmon, D. (Creator), Pomerantz, L. (Writer), \& Cackowski, L. (Story editor). (2010). Interpretive dance [Television series episode]. In G. Donovan, G. Foster, N. Goldman, D. Harmon, T. Hobert, R. Krasnoff, A. Russo, \& J. Russo (Executive producers), Community. Los Angeles, CA: National Broadcasting Company.

Hunt, E. (2016, May 27). Pair of glasses left on US gallery floor mistaken for art. The Guardian. Retrieved from www.theguardian.com/us-news/2016/may/27/pair-of-glasses-lefton-us-gallery-floor-mistaken-for-art

Ilchi, L. (2019, December 10). The $\$ 120,000$ art banana gets the meme treatment. WWD. Retrieved from https://wwd.com/fashion-news/fashion-scoops/art-basel-2019-artbanana-memes-1203395572/ 
Johnson, J. (2002). Who needs classical music? Cultural choice and musical value. Oxford: Oxford University Press.

Jones, T. (2019, August 8). Birmingham tops league of cities for attracting Londoners. Business Live. Retrieved from www.business-live.co.uk/enterprise/birmingham-topsleague-cities-attracting-16716270

Kawashima, N. (2000). Beyond the division of attenders vs non-attenders: A study into audience development in policy and practice. Centre for cultural policy studies: University of Warwick. Research Papers, 6. Retrieved from https://pdfs.semanticscholar.org/ 8905/c34d56a38b20b8ea09b8d49bf4d46285abcd.pdf?_ga=2.256192843.1532160863. $1578687181-1736036054.1578687181$

Kolb, B. M. (2001). The effect of generational change on classical music concert attendance and orchestras' responses in the UK and US. Cultural Trends, 11(41), 1-35. doi:10.1080/ 09548960109365147

Levitan, S. (Creator), Lloyd, C. (Creator), Richman, J. (Writer), \& Walls, R. (Executive story editor). (2016). Grab It [Television series episode]. In V. Chandrasekaran, P. Corrigan, A. Gordon, A. Higginbotham, E. Ko, S. Levitan, C. Lloyd, S. Lloyd, J. Morton, J. Pollack, J. Richman, C. Tatham, B. Walsh, \& D. Zuker (Executive producers). Modern family. Los Angeles, CA: American Broadcasting Company.

Liverpool City Council. (2013). 2011 Census: Ethnicity and migration. Retrieved from https://liverpool.gov.uk/media/9899/ethnicity-and-migration.pdf

Pitts, S. E. (2005). What makes an audience? Investigating the roles and experiences of listeners at a chamber music festival. Music and Letters, 86, 257-269. doi:10.1093/ml/gci035

Pitts, S. E. (2016). On the edge of their seats: Comparing first impressions and regular attendance in arts audiences. Psychology of Music, 44, 1175-1192. doi:10.1177/0305735615615420

Pitts, S. E., \& Gross, J. (2017). 'Audience exchange': Cultivating peer-to-peer dialogue at unfamiliar arts events. Arts and the Market, 7, 65-79. doi:10.1108/AAM-04-2016-0002

Pitts, S. E., \& Spencer, C. P. (2008). Loyalty and longevity in audience listening: Investigating experiences of attendance at a chamber music festival. Music and Letters, 89, 227-238. doi: $10.1093 / \mathrm{ml} / \mathrm{gcm} 084$

Reynolds, N. (2001, December 10). Turner Prize won by man who turns lights off. The Telegraph. Retrieved from www.telegraph.co.uk/news/uknews/1364860/Turner-Prizewon-by-man-who-turns-lights-off.html

Ross, A. (2007). The rest is noise: Listening to the twentieth century. London: HarperCollins.

Ross, A. (2010, November 28). Why do we hate modern classical music? The Guardian. Retrieved from www.theguardian.com/music/2010/nov/28/alex-ross-modern-classical-music

Smith, M. (2016, October 10). But is it art? According to most people, definitely not. YouGov. Retrieved from https://yougov.co.uk/topics/lifestyle/articles-reports/2016/10/10/ it-art-according-general-public-probably-not

Taking Part Survey. (2016). Taking part survey: Who participates? - Arts [Data tool]. Retrieved from https://public.tableau.com/profile/taking.part.survey\#!/vizhome/WhoParticipatesArts/Responsesbreakdowns

Visit Britain/Rod Edward. (2019). Visitor attraction trends in England 2018: Full report. Retrieved from www.visitbritain.org/sites/default/files/vb-corporate/annual_attractions_ survey_2018_trends_report.pdf

Wilson, N., Gross, J., \& Bull, A. (2017). Towards cultural democracy: Promoting cultural capabilities for everyone. Retrieved from www.kcl.ac.uk/cultural/resources/reports/towardscultural-democracy-2017-kcl.pdf

YouGov. (2016, October 5-7). YouGov survey results [Dataset]. YouGov. Retrieved from https://d25d2506sfb94s.cloudfront.net/cumulus_uploads/document/wqim3twtqg/ InternalResults_161007_ArtMerge_W.pdf 
How would I describe the kinds of arts events I go to?

(noror)
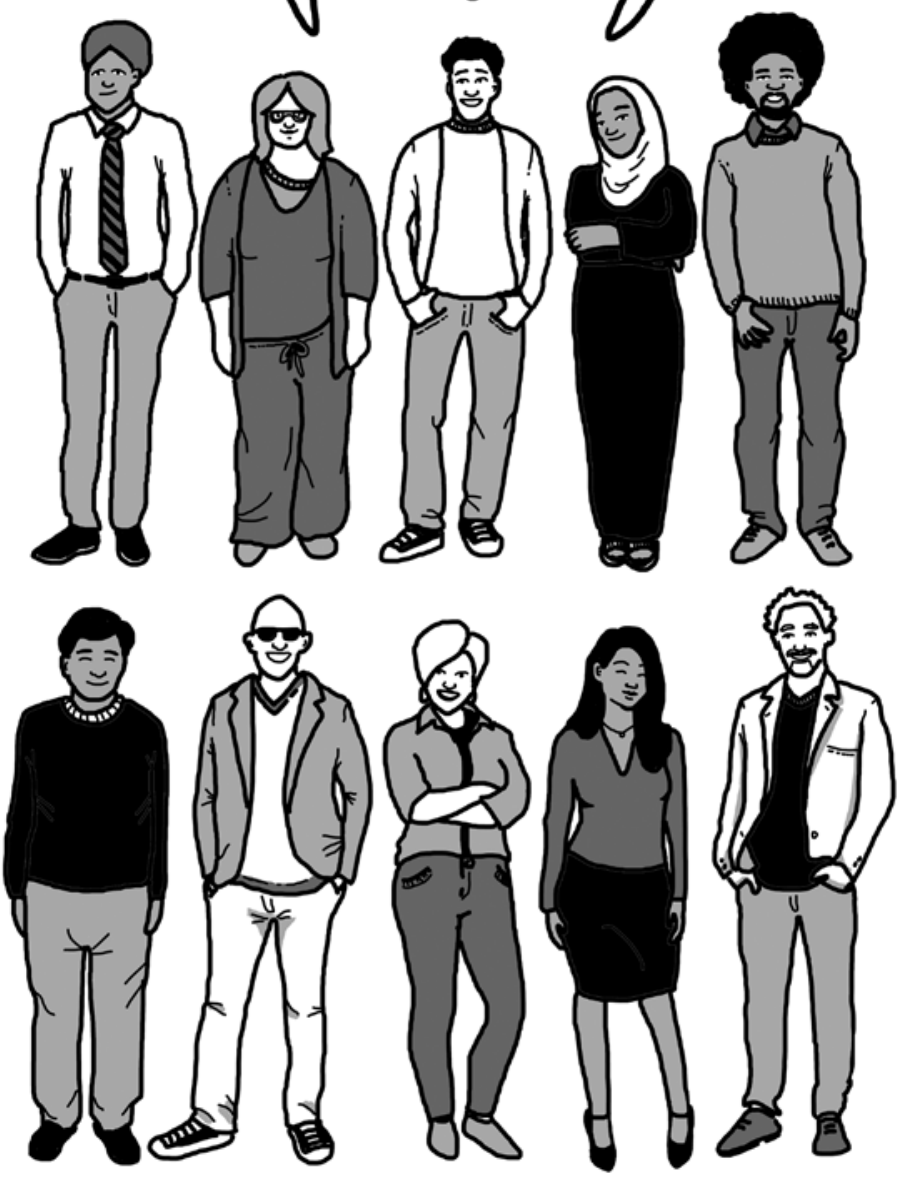


\section{References}

1 General Certificate of Secondary Education: school examinations taken by students aged 16 in the UK in which dance is an optional subject choice taken by around 8,000 people each year.

1 www.theaudienceagency.org/audience-spectrum/metroculturals

1 www.gov.uk/guidance/taking-part-survey

2 Stan's Cafe's It's Your Film.

3 A late-night radio programme on BBC Radio 3, which prides itself on playing eclectic music, with the current tagline: 'Experimental music for adventurous listeners'.

4 www.culturefeast.org/

5 Anonymous evaluation surveys (coded CFES) were conducted after each Culture Feast and four 'feasters' (coded CF1-4) were interviewed about their experiences. In addition, Sarah attended almost all the Culture Feast events for the first two iterations and spoke to the ticket-holders at length about their experiences.

1 The Audience Agency's Audience spectrum pen portraits: Explore the profile. Retrieved from: www. theaudienceagency.org/off-the-shelf/audience-spectrum/profiles

2 Percentages have been rounded up, and exclude the six interviews in which the question was not asked due to time spent on other topics, and so no assumptions were made about whether the arts were the main interest for those participants.

1 www.theaudienceagency.org/audience-spectrum/experience-seekers

$1 \quad 14.8 \%$ 'agreed' and $2.7 \%$ 'strongly agreed' $(n=2,468)$.

$221.9 \%$ 'agreed' and $2.5 \%$ 'strongly agreed'.

3 This participant is alluding to the British stereotype of unfriendly rural pubs, in which regulars, occupying the same chair every evening, are unwelcoming towards outsiders who are instantly recognised as not being from their community.

4 www.everydayparticipation.org/

5 https://64millionartists.com/

6 http://funpalaces.co.uk/

7 www.creativepeopleplaces.org.uk/

8 www.bespectactive.eu/

9 Open Space Technology is a method of structuring free discussion around a central topic, in which participants choose the themes that are most important to them, and a series of parallel debates occur within the same space, with participants encouraged to move between conversations when they feel they are not contributing to, or learning from, their current situation (Owen, 2008).

10 See report on the SPARC website: Open Space: 'We're all participants now - so what's the future for presentational arts?', www.sparc.dept.shef.ac.uk/open-space-2018/

11 www.artybollocks.com/

1 www.artscouncil.org.uk/case-studies/new-rules

2 www.sparc.dept.shef.ac.uk/uaca/handbook/

Adamou, A., Brown, S., Barlow, H., Allocca, C., \& d'Aquin, M. (2019). Crowdsourcing linked data on listening experiences through reuse and enhancement of library data. International Journal on Digital Libraries, 20, 61-79. doi:10.1007/s00799-018-0235-0

Bagley, C. A. (2012). Chapter 6: Embracing Twitter as a research tool. In G. Widén \& K. Holmberg (Eds.), Social information research (Library and Information Science, Volume 5) [E-reader version] (pp. 131-147). Bingley: Emerald Group Publishing Limited. doi:10.1108/S18760562(2012)0000005008

Barker, M. (2006). I have seen the future and it is not here yet . . ; Or, on being ambitious for audience research. The Communication Review, 9, 123-141. doi:10.1080/10714420600663310

Barker, M. (2013). Live at cinema near you: How audiences respond to digital streaming of the arts. In J. Radbourne, H. Glow, \& K. Johanson (Eds.), The audience experience: A critical analysis of audiences in the performing arts (pp. 15-34). Bristol: Intellect.

Barz, G. F., \& Cooley, T. J. (Eds.). (2008). Shadows in the field: New perspectives for fieldwork in ethnomusicology. New York: Oxford University Press.

Behr, A. (2017). Where the snowman meets the sunshine: The tensions between research, engagement and impact in cultural policy. Participations: Journal of Audience \& Reception Studies, 14(1), 352-375. Retrieved from www.participations.org/Volume\%2014/Issue\%201/21.pdf 
Bennett, S. (1997). Theatre audiences: A theory of production and reception (2nd ed.). Oxford, USA and Canada: Routledge.

Benzecry, C. E. (2011). The opera fanatic: Ethnography of an obsession. Chicago: The University of Chicago Press.

Blume-Kohout, M. E., Leonard, S. R., \& Novak-Leonard, J. L. (2015). When going gets tough: Barriers and motivations affecting arts attendance. Retrieved from www.arts.gov/sites/ default/files/when-going-gets-tough-revised2.pdf

Burland, K., \& Pitts, S. E. (2010). Understanding jazz audiences: Listening and learning at the Edinburgh Jazz and Blues Festival. Journal of New Music Research, 39, 125-134. doi:10. 1080/09298215.2010.493613

Burland, K., \& Pitts, S. E. (Eds.). (2014). Coughing and clapping: Investigating audience experience. Farnham, Surrey, England: Ashgate Publishing.

Clarke, E., Dibben, N., \& Pitts, S. (2010). Music and mind in everyday life. New York: Oxford University Press.

Conner, L. (2013). Audience engagement and the role of arts talk in the digital era. New York: Palgrave Macmillan.

Corbett, B., \& Edwards, A. (2018). A case study of Twitter as a research tool. Sports in Society, 21, 394-412. doi:10.1080/17430437.2017.1342622

Coyle, A. (2007). Discourse analysis. In E. Lyons \& A. Coyle (Eds.), Analysing qualitative data in psychology (pp. 98-116). London: Sage.

Dobson, M. C., \& Sloboda, J. (2014). Staying behind: Explorations in post-performance musician-audience dialogue. In K. Burland \& S. E. Pitts (Eds.), Coughing and clapping: Investigating audience experience (pp. 159-173). Farnham: Ashgate Publishing.

Egermann, H., Sutherland, M. E., Grewe, O., Nagel, F, Kopiez, R., \& Altenmüller, E. (2011). Does music listening in a social context alter experience? A physiological and psychological perspective on emotion. Musicae Scientiae, 15, 307-323. doi:10.1177/1029864911399497

Finney, J., \& Laurence, F. (2013). Masterclass in music education: Transforming teaching and learning. London: Continuum.

Freshwater, H. (2009). Theatre and audience. Basingstoke: Palgrave Macmillan.

Fricker, K. (2015). The futures of theatre criticism. Canadian Theatre Review, 163, 49-53. doi: $10.3138 /$ ctr. 163.010

Glass, R., \& Stevens, C. (2005). Making sense of contemporary dance: An Australian investigation into audience interpretation and enjoyment levels. Retrieved from http://citeseerx.ist.psu.edu/ viewdoc/download?doi=10.1.1.553.9501\&rep $=$ rep1\&type $=$ pdf

Griffiths, L., Eringa, W., Ellwood, N., Walmsley, B., \& Dunn, A. (2015). Yorkshire dance: Online engagement platform. Retrieved from https://webarchive.nationalarchives.gov. uk/20161104003001uo_/http://artsdigitalrnd.org.uk/wp-content/uploads/2013/10/ Yorkshire-Dance-Final-Project-Report.pdf

Hanquinet, L. (2013). Visitors to modern and contemporary art museums: Towards a new sociology of 'cultural profiles'. The Sociological Review, 61, 790-813. doi:10.1111/ 1467-954X.12072

Heim, C. (2016). Audience as performer: The changing role of theatre audiences in the twenty-first century. Abingdon and New York: Routledge.

Hennion, A. (2001). Music lovers: Taste as performance. Theory, Culture E Society, 18(5), 1-22. doi:10.1177/02632760122051940

Karlsen, S. (2009). Learning through music festivals. International Journal of Community Music, 2, 129-141. doi:10.1386/ijcm.2.2-3.129_1 
Litvin, S. W., \& Hoffman, L. M. (2012). Responses to consumer-generated media in the hospitality marketplace: An empirical study. Journal of Vacation Marketing, 18, 135-145. doi:10.1177/1356766712443467

O'Reilly, D. (2011). Mapping the arts marketing literature. Arts Marketing: An International Journal, 1, 26-38. doi:10.1108/20442081111129851

O'Sullivan, T. (2009). All together now: A symphony orchestra audience as a consuming community. Consumption Markets \& Culture, 12, 209-223. doi:10.1080/10253860903063220

Perry, C., \& Gummesson, E. (2004). Action research in marketing. European Journal of Marketing, 38, 310-320. doi:10.1108/03090560410518567

Pitts, S. E. (2005a). Valuing musical participation. Aldershot: Ashgate.

Pitts, S. E. (2005b). What makes an audience? Investigating the roles and experiences of listeners at a chamber music festival. Music and Letters, 86, 257-269. doi:10.1093/ml/gci035

Pitts, S. E. (2014). Musical, social and moral dilemmas: Investigating audience motivations to attend concerts. In K. Burland \& S. E. Pitts (Eds.), Coughing and clapping: Investigating audience experience (pp. 21-33). Farnham: Ashgate.

Pitts, S. E. (2016). On the edge of their seats: Comparing first impressions and regular attendance in arts audiences. Psychology of Music, 44, 1175-1192. doi:10.1177/0305735615615420

Pitts, S. E., \& Gross, J. (2017). 'Audience exchange': Cultivating peer-to-peer dialogue at unfamiliar arts events. Arts and the Market, 7, 65-79. doi:10.1108/AAM-04-2016-0002

Pitts, S. E., \& Price, S. M. (2019). Understanding audiences for the contemporary arts. Retrieved from www.sparc.dept.shef.ac.uk/uaca/handbook/

Price, S. M. (2015). Academic and commercial research: Bridging the gap. Participations: Journal of Audience E Reception Studies, 12(2), 168-173. Retrieved from www.participations. org/Volume\%2012/Issue\%202/9.pdf

Price, S. M. (2017). Risk and reward in classical music concert attendance: Investigating the engagement of 'art' and 'entertainment' audiences with a regional symphony orchestra in the UK (Doctoral dissertation). Retrieved from http://etheses.whiterose.ac.uk/16628/

Price, S., Perry, R., Mantell, O., Trinder, J., \& Pitts, S. (2019). Spontaneity and planning in arts attendance: Insights from qualitative interviews and the audience finder database. Cultural Trends, 28(2-3), 220-238. doi:10.1080/09548963.2019.1617943

Radbourne, J., Glow, H., \& Johanson, K. (Eds.). (2013). The audience experience: A critical analysis of audiences in the performing arts. Bristol: Intellect.

Radbourne, J., Johanson, K., Glow, H., \& White, T. (2009). The audience experience: Measuring quality in the performing arts. International Journal of Arts Management, 11(3), 16-29.

Reason, M. (2010). The young audience: Exploring and enhancing children's experiences of theatre. Stoke-on-Trent: Trentham Books Limited.

Reason, M., \& Lindelof, A. M. (Eds.). (2016). Experiencing liveness in contemporary performance: Interdisciplinary perspectives. New York: Routledge.

Reason, M., \& Reynolds, D. (2010). Kinesthesia, empathy, and related pleasures: An inquiry into audience experiences of watching dance. Dance Research Journal, 42(2), 49-75.

Reason, M., \& Sedgman, K. (2015). Editors' introduction: Themed section on theatre audiences. Participations: Journal of Audience \& Reception Studies, 12(1), 117-122. Retrieved from www.participations.org/Volume\%2012/Issue\%201/8.pdf

Renert, H., Russell-Mayhew, S., \& Arthur, N. (2013). Recruiting ethnically diverse participants into qualitative health research: Lessons learned. The Qualitative Report, 18(23), 1-13.

Robinson, R. (2016). Music festivals and the politics of participation. Abingdon and New York: Routledge.

Robson, C., \& McCartan, K. (2016). Real world research: A resource for users of social research methods in applied settings (4th ed.). Chichester: Wiley \& Sons. 
Savage, M. (2015). Social class in the 21st century. London: Pelican Books.

Sedgman, K. (2016). Locating the audience: How people found value in national theatre wales. Bristol: Intellect.

Sedgman, K. (2017). Ladies and gentlemen follow me, please put on your beards: Risk, rules, and audience reception in national theatre wales. Contemporary Theatre Review, 27, 158-176. doi:10.1080/10486801.2017.1300153

Sedgman, K. (2018). The reasonable audience: Theatre etiquette, behaviour policing, and the live performance experience. Cham: Palgrave Pivot.

Sedgman, K. (2019a). Challenges of cultural industry knowledge exchange in live performance audience research. Cultural Trends, 28, 103-117. doi:10.1080/09548963.2019.1617930

Sedgman, K. (2019b). On rigour in theatre audience research. Contemporary Theatre Review, 29, 462-479. doi:10.1080/10486801.2019.1657424

Sifakakis, S. (2007). Contemporary art's audiences: Specialist accreditation and the myth of inclusion. European Journal of Cultural Studies, 10,203-223. doi:10.1177/1367549407075908

Smith, J. A. (2019). Participants and researchers searching for meaning: Conceptual developments for interpretative phenomenological analysis. Qualitative Research in Psychology, 16, 161-181. doi:10.1080/14780887.2018.1540648

Smith, J. A., \& Osborn, M. (2003). Interpretative phenomenological analysis. In J. A. Smith (Ed.), Qualitative psychology: A practical guide to research methods (3rd ed., pp. 25-52). London: Sage.

Walmsley, B. (2016). From arts marketing to audience enrichment: How digital engagement can deepen and democratize artistic exchange with audiences. Poetics, 58, 66-78. doi:10.1016/j.poetic.2016.07.001

Walmsley, B. (2018). Deep hanging out in the arts: An anthropological approach to capturing cultural value. International Journal of Cultural Policy, 24, 272-291. doi:10.1080/1028 6632.2016.1153081

Walmsley, B. (2019). Audience engagement in the performing arts: A critical analysis. Cham: Palgrave Macmillan.

Williamson, J., Cloonan, M., \& Frith, S. (2011). Having an impact? Academics, the music industries and the problem of knowledge. International Journal of Cultural Policy, 17, 459-474. doi:10.1080/10286632.2010.550682

Willis, J. W., \& Edwards, C. (2014). Theoretical foundations for the practice of action research. In J. W. Willis \& C. Edwards (Eds.), Action research: Models, methods, and examples (pp. 21-43). Charlotte: Information Age Publishing.

Auslander, P. (2008). Liveness: Performance in a mediatized culture (2nd ed.). Oxford, New York and Canada: Routledge.

Bedinghaus, T. (2019, January 10). What is contemporary dance? [Webpage] LiveAbout. Retrieved from www.liveabout.com/what-is-contemporary-dance-1007423

Blocker, J. (2015). Becoming past: History in contemporary art. Minneapolis: University of Minnesota Press.

Boughen,S. (2014,June15).Explainer:Whatiscontemporarydance? The Conversation.Retrieved from https://theconversation.com/explainer-what-is-contemporary-dance-25713

Chilvers, I., \& Glaves-Smith, J. (2015). Contemporary art. In I. Chilvers \& J. Glaves-Smith (Eds.), The Oxford dictionary of modern and contemporary art [Online] (3rd ed.). Retrieved from www. oxfordreference.com/view/10.1093/acref/9780191792229.001.0001/acref9780191792229-e-581?rskey $=J q y S z R \&$ result $=590$

Cottingham, D. (2005). Modern art: A very short introduction. New York: Oxford University Press.

Crombie, N. (Director), \& Lord, D. (Executive Producer). (2012). All in the best possible taste with Grayson Perry [Television mini-series]. London: Seneca Productions. 
Daldry, S. (Director), Hall, L. (Writer), Brand, C., Ross, T., Thompson, D. M., \& Wharton, N. (Executive Producers). (2000). Billy Elliot [Motion picture]. Universal City, CA: Universal Pictures.

Danto, A. C. (1997). After the end of art: Contemporary art and the pale of history. Princeton, NJ: Princeton University Press.

Dempster, E. (2008). The choreography of the pedestrian. Performance Research, 13(1), 23-28.

Esaak, S. (2019, July 24). What is contemporary art? [Blog post] ThoughtCo. Retrieved from www.thoughtco.com/what-is-contemporary-art-182974

Foster, H., Bryan-Wilson, J., Kester, G., Elkins, J., Kwon, M., Shannon, J., . . . Mcdonough, T. (2009). Questionnaire on 'The Contemporary'. October, 130, 3-125.

Gardner, L. (2018, April 3). Othello as an out lesbian: Why Golda Rosheuvel's time is now. The Guardian. Retrieved from www.theguardian.com/stage/2018/apr/03/othelloas-an-out-lesbian-why-golda-rosheuvels-time-is-now

Haydon, A. (2008, November 4). Fringe theatre is too conventional. The Guardian. Retrieved from www.theguardian.com/stage/theatreblog/2008/nov/04/fringe-theatre

Huyssen, A. (1986). After the great divide: Modernism, mass culture, postmodernism. Bloomington, IN: Indiana University Press.

Johnston, K. M., Vollans, E., \& Greene, F. L. (2016). Watching the trailer: Researching the film trailer audience. Participations: Journal of Audience \& Reception Studies, 13(2), 56-85. Retrieved from www.participations.org/Volume\%2013/Issue\%202/5.pdf

Kwan, S. (2017). When is contemporary dance? Dance Research Journal, 49(3), 38-52.

Little, S. (2004). -Isms: Understanding art. New York: Universe.

Mackrell, J. (2016, November 2). Bourne's supremacy: The blockbuster choreographer puts on The Red Shoes. The Guardian. Retrieved from www.theguardian.com/stage/2016/ nov/02/matthew-bourne-the-red-shoes-interview-sadlers-wells

Miesfjord, T. (2020). CGI moments that have aged terribly [Webpage]. Looper. Retrieved from www.looper.com/154175/cgi-moments-that-have-aged-terribly/

Meyer, R. (2013). When was contemporary art? Cambridge, MA \& London: The MIT Press.

Negus, K. (1993). Plugging and programming: Pop radio and record promotion in Britain and the United States. Popular Music, 12, 57-68. doi:10.1017/S0261143000005353

Perry, G. (2013). Playing to the gallery: 2013. The Reith Lectures [Radio series]. London: British Broadcasting Corporation.

Perry, G. (2014). Playing to the gallery: Helping contemporary art in its struggle to be understood. London: Penguin.

Pitts, S. E., Dobson, M. C., Gee, K. A., \& Spencer, C. P. (2013). Views of an audience: Understanding the orchestral concert experience from player and listener perspectives. Participations: Journal of Audience and Reception Studies, 10(2), 65-95. Retrieved from www. participations.org/Volume\%2010/Issue\%202/5.pdf

Place, The. [Planet Dance]. (2015, January 16). Planet dance: A visitor's guide to contemporary dance [YouTube]. Retrieved from www.youtube.com $/$ watch? $\mathrm{v}=4 \mathrm{aeBhLakp} 3 \mathrm{c} \&$ feature $=$ youtu.be

Price, S. M. (2017). Risk and reward in classical music concert attendance: Investigating the engagement of 'art' and 'entertainment' audiences with a regional symphony orchestra in the UK (Doctoral dissertation). Retrieved from http://etheses.whiterose.ac.uk/16628/

Schuhbeck, B. (2012, February 22). Less art, more substance. New tendencies in contemporary theatre [Blog post]. Notes on Metamodernism. Retrieved from www. metamodernism.com/2012/02/22/less-art-more-substance-new-tendencies-in-contemporarytheatre/ 
Sierz, A. (2008, December 17). New writing in Britain: How do we define contemporary? [Blog post] The Sidcup Papers. Retrieved from http://theatrefutures.org.uk/sidcup_ papers/2008/12/17/new-writing-in-britain-how-do-we-define-the-contemporary/

Silka, P., alias of Ksenija Pantelić. (2016, March 30). What is contemporary art and how can we define it today? [Webpage] Widewalls. Retrieved from www.widewalls.ch/ what-is-contemporary-art/

Smith, T. (2009). What is contemporary art? Chicago: The University of Chicago Press.

Smith, T. (2010). The state of art history: Contemporary art. The Art Bulletin, 92, 366-383. doi:10.1080/00043079.2010.10786119

Stallabrass, J. (2004). Contemporary art: A very short introduction. Oxford: Oxford University Press.

Théberge, P. (2001). 'Plugged in': Technology and popular music. In S. Frith, W. Straw, \& J. Street (Eds.), The Cambridge companion to pop and rock (pp. 3-25). New York: Cambridge University Press.

Wasielewski, A. (2018). Made in Brooklyn: Artists, hipsters, makers, and gentrification. Alresford: Zero Books.

n.a. (2017, January 3). What is contemporary dance? [blog post]. The Dance Movement. Retrieved from www.thedancemovement.co.uk/blog/what-is-contemporary-dance

Arts Council England. (2018b). Bristol visual arts review. Retrieved from www.artscouncil.org.uk/ sites/default/files/download-file/ACE217\%20Bristol\%20Visual\%20Arts\%20Review.V7.pdf

Audiences London. (2012). Snapshot audience report: Sharing and comparing audience intelligence key indicators for performing arts venues in London. Retrieved from http://culturehive.co.uk/ wp-content/uploads/2013/04/Snapshot-Audience-Report-2009-10.pdf

Barrett, M. (2016). 'Our place': Class, the theatre audience and the Royal Court Liverpool (Doctoral dissertation). Retrieved from http://wrap.warwick.ac.uk/80890/1/WRAP_THESIS_ Barrett_2016.pdf

Behr, A., Brennan, M., Cloonan, M., Frith, S., \& Webster, E. (2016). Live concert performance: An ecological approach. Rock Music Studies, 3, 5-23. doi:10.1080/19401159.20 15.1125633

Boland, P. (2010). 'Capital of culture - you must be having a laugh!' Challenging the official rhetoric of Liverpool as the 2008 European Cultural Capital. Social \& Cultural Geography, 11, 627-645. doi:10.1080/14649365.2010.508562

Boland, P., Murtagh, B., \& Shirlow, P. (2019). Fashioning a City of Culture: 'Life and place changing' or '12 month party'? International Journal of Cultural Policy, 25, 246-265. doi:10. 1080/10286632.2016.1231181

Brook, O. (2013). Reframing models of arts attendance: Understanding the role of access to a venue. The case of opera in London. Cultural Trends, 22, 97-107. doi:10.1080/095 48963.2013.783175

Bryson, J. R. (2007). Arts, dance, cultural infrastructure, and city regeneration: Knowledge, audience development, networks, and conventions, and the relocation of a Royal Ballet company from London to Birmingham. Norsk Geografisk Tidsskrift-Norwegian Journal of Geography, 61, 98-110. doi:10.1080/00291950701553848

Campbell, P., Cox, T., \& O’Brien, D. (2017). The social life of measurement: How methods have shaped the idea of culture in urban regeneration. Journal of Cultural Economy, 10, 49-62. doi:10.1080/17530350.2016.1248474

Cohen, S. (2012). Live music and urban landscape: Mapping the beat in Liverpool. Social Semiotics, 22, 587-603. doi:10.1080/10350330.2012.731902 
Cox, T., \& O'Brien, D. (2012). The 'scouse wedding' and other myths: Reflections on the evolution of a 'Liverpool model' for culture-led urban regeneration. Cultural Trends, 21, 93-101. doi:10.1080/09548963.2012.674749

Culture, Place and Policy Institute (CPPI). (2019). Cultural transformations: The impacts of Hull UK City of Culture 2017: Main evaluation findings and reflections. Hull: University of Hull.

Dobson, J. (2018). From contest to context: Urban green space and public policy. People, Place and Policy, 12, 72-83. doi:10.3351/ppp.2018.3824435278

Evans, G. (2005). Measure for measure: Evaluating the evidence of culture's contribution to regeneration. Urban Studies, 42, 959-983. doi:10.1080/00420980500107102

Garcia, B. (2004). Urban regeneration, arts programming and major events: Glasgow 1990, Sydney 2000 and Barcelona, 2004. International Journal of Cultural Policy, 10, 103-118. doi:10.80/1028663042000212355

Garcia, B. (2005). Deconstructing the city of culture: The long-term cultural legacies of Glasgow 1990. Urban Studies, 42, 841-868. doi:10.1080/00420980500107532

Garrido, S., \& Macritchie, J. (2018). Audience engagement with community music performances: Emotional contagion in audiences of 'pro-am' orchestra in suburban Sydney. Musicae Scientiae. doi:10.1177/1029864918783027

Gomes, P., \& Librero-Cano, A. (2018). Evaluating three decades of the European Capital of Culture programme: A difference-in-differences approaches. Journal of Cultural Economics, 42, 57-73. doi:10.1007/s10824-016-9281-x

Griffiths, R., Bassett, K., \& Smith, I. (1999). Cultural policy and the cultural economy in Bristol. Local Economy: The Journal of the Local Economy Policy Unit, 14, 257-264. doi:10.1080/02690949908726496

Grimley, T. (2014). Symphony hall: A dream realised. Birmingham: Performances Birmingham.

Gross, J., \& Pitts, S. (2016). Audiences for the contemporary arts: Exploring varieties of participation across art forms in Birmingham, UK. Participations: Journal of Audience \& Reception Studies, 13(1), 4-23. Retrieved from www.participations.org/Volume\%2013/ Issue $\% 201 / 2$.pdf

Holden, J. (2015). The ecology of culture. Retrieved from https://ahrc.ukri.org/documents/ project-reports-and-reviews/the-ecology-of-culture/

Leonard, M., \& Strachan, R. (Eds.). (2010). The beat goes on: Liverpool, popular music and the changing city. Liverpool: Liverpool University Press.

Liu, Y.-D. (2016). Cultural event and urban regeneration: Lessons from Liverpool as the 2008 European capital of culture. European Review, 24, 159-176. doi:10.1017/ S1062798715000265

Liu, Y.-D. (2017). Quality of life as event legacy: An evaluation of Liverpool as the 2008 European capital of culture. Applied Research in Quality of Life, 12, 653-670. doi:10.1007/ s11482-016-9481-8

Mooney, G. (2004). Cultural policy as urban transformation? Critical reflections on Glasgow, European city of culture. Local Economy: The Journal of the Local Economy Policy Unit, 19, 327-340. doi:10.1080/0269094042000286837

O'Brien, D. (2010). 'No cultural policy to speak of' - Liverpool 2008. Journal of Policy Research in Tourism, Leisure and Events, 2, 113-128. doi:10.1080/19407963.2010.482271

O'Sullivan, T. (2009). All together now: A symphony orchestra audience as a consuming community. Consumption Markets \& Culture, 12, 209-223. doi:10.1080/10253860903063220

Office for National Statistics. (2019). Population estimates for the UK, England and Wales, Scotland and Northern Ireland: Mid-2018. Retrieved from www.ons.gov.uk/people populationandcommunity/populationandmigration/populationestimates/bulletins/ annualmidyearpopulationestimates/mid2018\#local-population-change 
Pitts, S. E. (2005). What makes an audience? Investigating the roles and experiences of listeners at a chamber music festival. Music and Letters, 86, 257-269. doi:10.1093/ml/gci035

Pitts, S. E., Price, S., \& Freshwater, H. (Forthcoming). 'I'd see anything': Exploring potential fandom in highly engaged theatre audiences. In K. Sedgman (Ed.), Introduction to theatre fandom. Scheduled for publication in 2020 with University of Iowa Press.

Pitts, S. E., \& Spencer, C. P. (2008). Loyalty and longevity in audience listening: Investigating experiences of attendance at a chamber music festival. Music and Letters, 89, 227-238. doi: $10.1093 / \mathrm{ml} / \mathrm{gcm} 084$

Price, S. M. (2017). Risk and reward in classical music concert attendance: Investigating the engagement of 'art' and 'entertainment' audiences with a regional symphony orchestra in the UK (Doctoral dissertation). Retrieved from http://etheses.whiterose.ac.uk/16628/

Price, S. M., Perry, R., Mantell, O., Trinder, J., \& Pitts, S. (2019). Spontaneity and planning in arts attendance: Insights from qualitative interviews and the audience finder database. Cultural Trends, 28(2-3), 220-238. doi:10.1080/09548963.2019.1617943

Reason, M., \& Garcia, B. (2007). Approaches to the newspaper archive: Content analysis and press coverage of Glasgow's year of culture. Media, Culture \& Society, 29, 304-331. doi:10.1177/0163443707074261

Rice, E. M. (2018, August 13). Cruise ships you can see in Liverpool in 2019. Liverpool Echo. Retrieved from www.liverpoolecho.co.uk/whats-on/whats-on-news/ see-cruise-ships-liverpool-2018-12422442

Sound Diplomacy. (2019). The music cities manual: How music increases economic, social and cultural growth in your city. Retrieved from www.sounddiplomacy.com/our-insights/musiccities-manual

Stark, P., Gordon, C., \& Powell, D. (2013). Rebalancing our cultural capital. Retrieved from www.gpsculture.co.uk/downloads/rocc/Rebalancing_FINAL_3mb.pdf

Tapper, J. (2019, June 29). Tired of London: Thousands flee capital for a quieter life. The Guardian. Retrieved from www.theguardian.com/uk-news/2019/jun/29/tired-of-londonthousands-flee-capital-for-a-quieter-life

Tommarchi, E., Hansen, L. E., \& Bianchini, F. (2018). Problematising the question of participation in capitals of culture. Participations: Journal of Audience \& Reception Studies, 15(2), 154-169. Retrieved from www.participations.org/Volume\%2015/Issue\%202/10.pdf

Warner, S. (2011). 'You only sing when you're winning': Football factions and rock rivalries in Manchester and Liverpool. Soccer and Society, 12, 58-73. doi:10.1080/14660970.2011.530468

Arts Council England. (2014). This England: How arts council England uses its investment to shape a national cultural ecology. Retrieved from www.artscouncil.org.uk/sites/default/ files/download-file/This_England_report.pdf

Baillie, G. (2015, September 22). Bro, do you even lit? [Blog post] The Strand. Retrieved from https://thestrand.ca/bro-do-you-even-lit/

Behr, A., Brennan, M., \& Cloonan, M. (2014). The cultural value of live music from the pub to the stadium: Getting beyond the numbers. Live Music Exchange. Retrieved from http:// livemusicexchange.org/wp-content/uploads/The-Cultural-Value-of-Live-Music-Pubto-Stadium-report.pdf

Behr, A., Brennan, M., Cloonan, M., Frith, S., \& Webster, E. (2016). Live concert performance: An ecological approach. Rock Music Studies, 3, 5-23. doi:10.1080/19401159.20 15.1125633

Behr, A., Webster, E., Brennan, M., Cloonan, M., \& Ansell, J. (2019). Making live music count: The UK Live Music Census. Popular music and Society, 1-23. doi:10.1080/03007 766.2019.1627658 
Brown, A. S., \& Novak-Leonard, J. L. (2013). Measuring the intrinsic impacts of arts attendance. Cultural Trends, 22, 223-233. doi:10.1080/09548963.2013.817654

Calouste Gulbenkian Foundation. (2017). Rethinking relationships: Inquiry into the civic role of arts organisations: Phase 1 report. London: Calouste Gulbenkian Foundation. Retrieved from http://civicroleartsinquiry.gulbenkian.org.uk/resources/rethinking-relationshipsphase-one-of-the-inquiry-into-the-civic-role-of-arts-organisations

Carnwath, J. D., \& Brown, A. S. (2014). Understanding the value and impacts of cultural experiences: A literature review. Manchester: Arts Council England. Retrieved from www. artscouncil.org.uk/sites/default/files/download-file/Understanding_the_Value_and_ Impacts_of_Cultural_Experiences.pdf

Carrington, M. J., Zwick, D., \& Neville, B. (2016). The ideology of the ethical consumption gap. Marketing Theory, 16, 21-38. doi:10.1177/1470593115595674

Csikszentmihalyi, M. (2013). Flow: The classic work on how to achieve happiness. London, Sydney, Auckland, and Johannesburg: Rider.

de Rooij, P. (2013). Customer loyalty to performing arts venues. Between routines and coincidence. (Doctoral Dissertation) Retrieved from https://pure.uvt.nl/ws/portalfiles/portal/1499760/ Rooij_Customer_13-03-2013.pdf

Doeser, J. (2014). This England: How arts council England uses its investment to shape a national cultural ecology. Cultural Trends, 23, 298-303. doi:10.1080/09548963.2014. 961299

Giesler, M., \& Veresiu, E. (2014). Creating the responsible consumer: Moralistic governance regimes and consumer subjectivity. Journal of Consumer Research, 41, 840-857. doi:10.1086/677842

Gross, J., \& Wilson, N. (2018). Cultural democracy: An ecological and capabilities approach. International Journal of Cultural Policy, 1-16. doi:10.1080/10286632.2018.1538363

Jenkins, C., \& Joven, J. (2018, March 13). Spotify: The rise of the contextual playlist [Blog post]. Retrieved from https://blog.chartmetric.io/spotify-the-rise-of-the-contextual-playlistc6f2c26900f4

Kyle, G., Graefe, A., Manning, R., \& Bacon, J. (2004). Effects of place attachment on users' perceptions of social and environmental conditions in a natural setting. Journal of Environmental Psychology, 24(2), 213-225.

Levine, L. W. (1990). Highbrow lowbrow: The emergence of cultural hierarchy in America. Boston: Harvard University Press.

Manzo, L. C., \& Perkins, D. D. (2006). Finding common ground: The importance of place attachment to community participation and planning. Journal of Planning Literature, 20, 335-350. doi:10.1177/0885412205286160

Martinez, C., Florence, E., \& Lallement, J. (2018). The importance of the venue in an information search: Online ticket purchase in the performing arts. International Journal of Arts Management, 20(3), 60-74.

McCarthy, J., \& Sanchez, E. (2019, April 17). The 'Attenborough effect' is causing plastic pollution to plummet [Blog post]. Global Citizen. Retrieved from www.globalcitizen.org/ en/content/attenborough-effect-plastics/

Newman, D. (1981). Subscribe now! Building arts audiences through dynamic subscription promotion. New York: Theatre Communications Group.

Paeth, S. (2018). Consumer activism. In R. Kolb (Ed.), The SAGE encyclopedia of business ethics and society (Vol. 1., pp. 628-632). Thousand Oaks, CA: Sage Publications. doi:10.4135/9781483381503.n232

Peterson, R. A., \& Kern, R. M. (1996). Changing highbrow taste: From snob to omnivore. American Sociological Review, 61, 90-907. doi:10.2307/2096460 
Pitts, S. E. (2014). Musical, social and moral dilemmas: Investigating audience motivations to attend concerts. In K. Burland \& S. E. Pitts (Eds.), Coughing and clapping: Investigating audience experience (pp. 21-33). Farnham: Ashgate.

Pitts, S. E. (2016). On the edge of their seats: Comparing first impressions and regular attendance in arts audiences. Psychology of Music, 44, 1175-1192. doi:10.1177/0305735615615420

Pitts, S. E., \& Gross, J. (2017). 'Audience exchange': Cultivating peer-to-peer dialogue at unfamiliar arts events. Arts and the Market, 7, 65-79. doi:10.1108/AAM-04-2016-0002

Pitts, S. E., Herrero, M., \& Price, S. M. (2020). Understanding the liminality of individual giving to the arts. Arts and the Market, 10(1), 18-33. https://doi.org/10.1108/ AAM-08-2019-0026

Pitts, S. E., \& Spencer, C. P. (2008). Loyalty and longevity in audience listening: Investigating experiences of attendance at a chamber music festival. Music and Letters, 89, 227-238. doi: $10.1093 / \mathrm{ml} / \mathrm{gcm} 084$

Plante, S. G. (2019, October 7). Shopping has become a political act. Here's how it happened [Blog post]. Vox. Retrieved from www.vox.com/the-goods/2019/10/7/20894134/ consumer-activism-conscious-consumerism-explained

Price, S. M. (2017). Risk and reward in classical music concert attendance: Investigating the engagement of 'art' and 'entertainment' audiences with a regional symphony orchestra in the UK (Doctoral dissertation). Retrieved from http://etheses.whiterose.ac.uk/16628/

Price, S. M., Perry, R., Mantell, O., Trinder, J., \& Pitts, S. (2019). Spontaneity and planning in arts attendance: Insights from qualitative interviews and the audience finder database. Cultural Trends, 28(2-3), 220-238. doi:10.1080/09548963.2019.1617943

Radbourne, J., Glow, H., \& Johanson, K. (Eds.). (2013). The audience experience: A critical analysis of audiences in the performing arts. Bristol: Intellect.

Rentschler, R., Radbourne, J., Carr, R., \& Rickard, J. (2002). Relationship marketing, audience retention and performing arts organisation viability. International Journal of Nonprofit and Voluntary Sector Market, 7, 118-130. doi:10.1002/nvsm.173

Sedgman, K. (2017b, August 4). Understanding theatre fans [Blog post]. Retrieved from www. thebritishacademy.ac.uk/blog/understanding-theatre-fans

Stark, P., Gordon, C., \& Powell, D. (2013). Rebalancing our cultural capital. Retrieved from www.gpsculture.co.uk/downloads/rocc/Rebalancing_FINAL_3mb.pdf

Turner, V. W. (1977). The ritual process: Structure and anti-structure. Ithaca NY: Cornell University Press.

Ulusoy, E. (2016). Experiential responsible consumption. Journal of Business Research, 69(1), 284-297.

Valor, C., Antonetti, P., \& Carrero, I. (2018). Stressful sustainability: A hermeneutic analysis. European Journal of Marketing, 52, 550-574. doi:10.1108/EJM-12-2016-0712

Wasielewski, A. (2018). Made in Brooklyn: Artists, hipsters, makers, and gentrification. Alresford: Zero Books.

Watson, C. (2015, May 22). 'Context is the new genre': Why it's all about the why [Blog post]. Medium. Retrieved from https://medium.com/soundwave-stories/context-isthe-new-genre-b5df54ca0b5

Weber Shandwick \& KRC Research. (2018). Battle of the wallets: The changing landscape of consumer activism. Retrieved from http://webershandwick.co.uk/wp-content/ uploads/2018/01/Battle-of-the-wallets-report-UK.pdf

Winzenried, R. (2004, January-February). Stalking the culturally aware non-attender. Symphony, 26-32.

Zolfagharian, M. A., \& Pentina, I. (2011). The tripartite model of responsible consumption. Social Business: An Interdisciplinary Journal, 1, 149-172. doi:10.1362/204440811X593054 
Arts Council England. (n.d.a). Dance education: A guide for governors and trustees. Retrieved from www.artscouncil.org.uk/sites/default/files/download-file/Dance_Education_Governors_ Trustees_0.pdf

Ashton, D., \& Gowland-Pryde, R. (2019). Arts audience segmentation: Data, profiles, segments and biographies. Cultural Trends, 28, 146-161. doi:10.1080/09548963.2019. 1617938

Belfiore, E., \& Bennett, O. (2007). Determinants of impact: Towards a better understanding of encounters with the arts. Cultural Trends, 16, 225-275. doi:10.1080/09548960701479417

Bernard, M., Rickett, M., Amigoni, D., Munro, L., Murray, M., \& Rezzano, J. (2015). Ageing and Society, 35, 1119-1145. doi:10.1017/S0144686X14000038

Booth, W. (1999). For the love of it: Amateuring and its rivals. Chicago and London: University of Chicago Press.

Bull, A. (2019). Class, control, and classical music. New York: Oxford University Press.

Chua, A. (2011). Battle Hymn of the Tiger Mother. New York: Penguin.

Craig, M. L. (2014). Sorry I don't dance: Why men refuse to move. New York: Oxford University Press.

Creech, A., Hallam, S., Varvarigou, M., \& McQueen, H. (2014). Active ageing with music: Supporting wellbeing in the third and fourth ages. London: Institute of Education Press.

Cunningham, M. (2018, January 1). The stage mom survival guide [Blog post]. Onstage Blog. Retrieved from www.onstageblog.com/columns/2018/1/1/the-stage-mom-survival-guide

Cutler, D. (2009). Ageing artfully: Older people and professional participatory arts in the UK. Retrieved from https://cdn.baringfoundation.org.uk/wp-content/uploads/2009/08/ AgeingArtfully.pdf

Daubney, A., Spruce, G., \& Annetts, D. (2019). Music education: State of the nation: Report by the all-party parliamentary group for music education, the incorporated society of musicians and the University of Sussex. Retrieved from www.ism.org/images/images/State-of-the-NationMusic-Education-WEB.pdf

Davidson, J. W., \& Borthwick, S. J. (2002). Family dynamics and family scripts: A case study of musical development. Psychology of Music, 30, 121-136. doi:10.1177/0305735602301009

Davidson, J. W., Sloboda, J. A., \& Howe, M. J. A. (1996). The role of parents and teachers in the success and failure of instrumental learners. Bulletin of the Council for Research in Music Education, 127, 40-44.

Downing, D., \& Watson, R. (2004). School art: What's in it? Exploring visual arts in secondary school. Retrieved from www.nfer.ac.uk/nfer/publications/VAL01/VAL01.pdf

Ericsson, K. A., Krampe, R. T., \& Tesch-Römer, C. (1993). The role of deliberate practice in the acquisition of expert performance. Psychological Review, 100, 363-406. doi: 10.1037/0033-295X.100.3.363

Flynn, P., \& Johnston, T. (2016). Possible selves in music. Dublin: Music Generation. Retrieved from www.musicgeneration.ie/about/research/

Gladwell, M. (2008). Outliers: The story of success. London: Penguin.

Gross, J., \& Pitts, S. (2016). Audiences for the contemporary arts: Exploring varieties of participation across art forms in Birmingham, UK. Participations: Journal of Audience $\mathcal{E}$ Reception Studies, 13(1), 4-23. Retrieved from www.participations.org/Volume\%2013/ Issue $\% 201 / 2$.pdf

Hallam, S. (2015). The power of music: A research synthesis of the impact of actively making music on the intellectual, social and personal development of children and young people. London: International Music Education Research Centre Press.

Holt, J. (1978). Never too late: My musical life story. Cambridge, MA: Perseus Books. 
Kolb, B. M. (2001). The effect of generational change on classical music concert attendance and orchestras' responses in the UK and US. Cultural Trends, 11(41), 1-35. doi:10.1080/09548960109365147

Liechty, T., Yarnal, C., \& Kerstetter, D. (2012). 'I want to do everything!' Leisure innovation among retirement-age women. Leisure Studies, 31, 389-408. doi:10.1080/0261436 7.2011.573571

Macnamara, B. N., Hambrick, D. Z., \& Oswald, F. K. (2014). Deliberate practice and performance in music, games, sports, education, and professions: A meta-analysis. Psychological Science, 25, 1608-1618. doi:10.1177/0956797614535810

Marques, L., \& Pimentel Biscaia, M. S. (2019). Leisure and innovation: Exploring boundaries. World Leisure Journal, 61, 162-169. doi:10.1080/16078055.2019.1639257

McPherson, G. E., Davidson, J. W., \& Faulkner, R. (2012). Music in our lives: Rethinking musical ability, development and identity. New York: Oxford University Press.

Miendlarzewska, E. A., \& Trost, W. J. (2014). How musical training affects cognitive development: Rhythm reward and other modulating variables. Frontiers in Neuroscience, 7, 1-9. doi:10.3389/fnins.2013.00279

Nisic, N., \& Petermann, S. (2013). New city = new friends? The restructuring of social resources after relocation. Comparative Population Studies, 38, 199-226. doi:10.4232/10. CPoS-2013-08en

Oskala, A., Keaney, E., Chan, T. W., \& Bunting, C. (2009). Encourage children today to build audiences for tomorrow. Arts Council England. Retrieved from http://users.ox.ac.uk/ sfos 0006/papers/children.pdf

Pickard, A. (2012). Schooling the dancer: The evolution of an identity as a ballet dance. Research in Dance Education, 13, 25-46. doi:10.1080/14647893.2011.651119

Pickard, A. (2013). Ballet body belief: Perceptions of an ideal ballet body from young ballet dancers. Research in Dance Education, 14, 3-19. doi:10.1080/14647893.2012.712106

Pitts, S. E. (2012). Chances and choices: Exploring the impact of music education. New York: Oxford University Press.

Pitts, S. E. (2013). Amateurs as audiences: Reciprocal relationships between playing and listening to music. In J. Radbourne, H. Glow, \& K. Johanson (Eds.), The audience experience: $A$ critical analysis of audiences in the performing arts (pp. 83-93). Bristol: Intellect.

Radbourne, J., Johanson, K., Glow, H., \& White, T. (2009). The audience experience: Measuring quality in the performing arts. International Journal of Arts Management, 11(3), 16-29.

Ruch, W., Platt, T., \& Hofmann, J. (2014). The character strengths of class clowns. Frontiers in Psychology, 5, 1-12. doi:10.3389/fpsyg.2014.01075

Schlaug, G., Norton, A., Overy, K., \& Winner, E. (2005). Effects of music training on the child's brain and cognitive development. Annals of the New York Academy of Sciences, 1060, 219-230. doi:10.1196/annals.1360.015

Schucan Bird, K., Tripney, J., \& Newman, M. (2013). The educational impacts of young people's participation in organised sport: A systematic review. Journal of Children's Services, 8(4), 264-275. doi:10.1108/JCS-04-2013-0014

Tajtáková, M., \& Arias-Aranda, D. (2008). Targeting university students in audience development strategies for opera and ballet. The Services Industries Journal, 28, 179-191. doi:10.1080/02642060701842191

What Works Wellbeing. (2017). Sport, dance and young people. Retrieved from www.one danceuk.org/resource/sport-dance-young-people/

Brown, A. (2004). Smart concerts: Orchestras in the age of edutainment. Retrieved from www. issuelab.org/resources/11138/11138.pdf 
Dobson, M. C. (2010). New audiences for classical music: The experiences of non-attenders at live orchestra concerts. Journal of New Music Research, 39, 111-124. doi:10.1080/0929 8215.2010 .489643

Feist, G., \& Brady, T. R. (2004). Openness to experience, non-conformity, and the preference for abstract art. Empirical Studies of the Arts, 22, 77-89. doi:10.2190/Y7CA-TBY6V7LR-76GK

Halpern, A. R., Chan, C. H. K., Müllensiefen, D., \& Sloboda, J. (2017). Audience reactions to repeating a piece on a concert programme. Participations: Journal of Audience \& Reception Studies, 14(2), 135-152. Retrieved from www.participations.org/Volume\%2014/Issue\% 202/7b.pdf

Johanson, K., \& Glow, H. (2015). A virtuous circle: The positive evaluation phenomenon in arts audience research. Participations: Journal of Audience E Reception Studies, 12(1), 254-270. Retrieved from www.participations.org/Volume\%2012/Issue\%201/16.pdf

Kolb, B. M. (2000). You call this fun? Reactions of young first-time attendees to a classical concert. Music and Entertainment Industry Educators Association Journal, 1(1), 13-28.

Pitts, S. E. (2016). On the edge of their seats: Comparing first impressions and regular attendance in arts audiences. Psychology of Music, 44,1175-1192. doi:10.1177/0305735615615420

Pitts, S. E., \& Gross, J. (2017). 'Audience exchange': Cultivating peer-to-peer dialogue at unfamiliar arts events. Arts and the Market, 7, 65-79. doi:10.1108/AAM-04-2016-0002

Pitts, S. E., Herrero, M., \& Price, S. M. (2020). Understanding the liminality of individual giving to the arts. Arts and the Market, 10(1), 18-33. https://doi.org/10.1108/ AAM-08-2019-0026

Price, S. M. (2017). Risk and reward in classical music concert attendance: Investigating the engagement of 'art' and 'entertainment' audiences with a regional symphony orchestra in the UK (Doctoral dissertation). Retrieved from http://etheses.whiterose.ac.uk/16628/

Schroeder, J. E. (2005). The artist and the brand. European Journal of Marketing, 39, 12911305. doi:10.1108/03090560510623262

Sifakakis, S. (2007). Contemporary art's audiences: Specialist accreditation and the myth of inclusion. European Journal of Cultural Studies, 10,203-223. doi:10.1177/1367549407075908

Sigurjonsson, N. (2010). Orchestra audience development and the aesthetics of 'customer comfort'. The Journal of Arts Management, Law and Society, 40, 266-278. doi:10.1080/10 632921.2010 .502011

Turrini, A., O'hare, M., \& Borgonovi, F. (2008). The border conflict between the present and the past: Programming classical music and opera. The Journal of Arts Management, Law and Society, 38, 71-88. doi:10.3200/JAML.38.1.71-88

Bennett, D., \& Ginsborg, J. (2018). Audience reactions to the program notes of unfamiliar music. Psychology of Music, 46, 588-605. Doi:10.1177/0305735617721339

Blom, D. M., Bennett, D., \& Stevenson, I. (2016). The composer's program note for newly written classical music: Content and intentions. Frontiers in Psychology, 7. Doi:10.3389/ fpsyg.2016.01707

Brown, A. S., \& Novak-Leonard, J. L. (2013). Measuring the intrinsic impacts of arts attendance. Cultural Trends, 22, 223-233. Doi:10.1080/09548963.2013.817654

Conner, L. (2013). Audience engagement and the role of arts talk in the digital era. New York: Palgrave Macmillan.

Conner, L. (2016). Taking back the arts: 21st century audiences, participatory culture and the end of passive spectatorship. L'Ordinaire des Amériques, 220. Doi:10.4000/ orda. 2773

Leinhardt, G., Crowley, K., \& Knutson, K. (Eds.). (2002). Learning conversations in museums. Mahwah, NJ: Lawrence Erlbaum Associates. 
Margulis, E. H. (2010). When program notes don't help: Music descriptions and enjoyment. Psychology of Music, 38, 285-302. Doi:10.1177/0305735609351921

O'Sullivan, T. (2009). All together now: A symphony orchestra audience as a consuming community. Consumption Markets \& Culture, 12, 209-223. Doi:10.1080/10253860903063220

Pitts, S. E., \& Gross, J. (2017). 'Audience exchange': Cultivating peer-to-peer dialogue at unfamiliar arts events. Arts and the Market, 7, 65-79. Doi:10.1108/AAM-04-20160002

Pitts, S. E., Price, S., \& Freshwater, H. (Forthcoming). 'I'd see anything': Exploring potential fandom in highly engaged theatre audiences. In K. Sedgman (Ed.), Introduction to theatre fandom. Scheduled for publication in 2020 with University of Iowa Press.

Price, S. M. (2017). Risk and reward in classical music concert attendance: Investigating the engagement of 'art' and 'entertainment' audiences with a regional symphony orchestra in the UK (Doctoral dissertation). Retrieved from http://etheses.whiterose.ac.uk/16628/

Price, S. M., Perry, R., Mantell, O., Trinder, J., \& Pitts, S. (2019). Spontaneity and planning in arts attendance: Insights from qualitative interviews and the audience finder database. Cultural Trends, 28(2-3), 220-238. Doi:10.1080/09548963.2019.1617943

Skydsgaard, M. A., Møller Anderson, H., \& King, H. (2016). Designing museum exhibits that facilitate visitor reflection and discussion. Museum Management and Curatorship, 31, 46-68. Doi:10.1080/09647775.2015.1117237

Smith, J. K. (2014). The museum effect: How museums, libraries, and cultural institutions educate and civilize society. Maryland: Rowman \& Littlefield.

Smith, L. F., Smith, J. K., \& Tinio, P. P. L. (2017). Time spent viewing art and reading labels. Psychology of Aesthetics, Creativity, and the Arts, 11, 77-85. Doi:10.1037/aca0000049

Arts Council England \& Consilium Research \& Consultancy. (2014). Equality and diversity within the arts and cultural sector in England 2013-16: Evidence review. Retrieved from www.artscouncil.org.uk/sites/default/files/download-file/Consilium_Equality_Diversity_ report_13112018.docx_0.pdf

Brookes, P. (2019, May 15). Diversity beyond visible representation. Arts Professional. Retrieved from www.artsprofessional.co.uk/magazine/article/diversity-beyond-visiblerepresentation

Bunting, C., Chan, T. W., Goldthorpe, J., Keaney, E., \& Oskala, A. (2008). From indifference to enthusiasm: Patterns of arts attendance in England. Arts Council England. Retrieved from http://users.ox.ac.uk/ sfos0006/papers/indifferencetoenthusiasm.pdf

Chris Madden Cartoons. (2020). A common view of modern art - The emperor's new clothes [cartoon]. Retrieved from www.chrismadden.co.uk/cartoon-gallery/a-common-view-ofmodern-art-the-emperors-new-clothes/

Dobson, M. C., \& Pitts, S. E. (2011). Classical cult or learning community? Exploring new audience members' social and musical responses to first-time concert attendance. Ethnomusicology Forum, 20(3), 353-383.

Genova, A. (2018, April 11). Activism in the art world: Meet the next generation of radical curators. The Guardian. Retrieved from www.theguardian.com/education/2018/apr/11/ activism-art-world-next-generation-radical-curators

Harrison, C. (2013, October 10). Why modern art really should be off the wall. Belfast Telegraph. Retrieved from www.belfasttelegraph.co.uk/life/features/why-modern-artreally-should-be-off-the-wall-29648492.html

Hodge, S. (2012). Why your five year old could not have done that: Modern art explained. New York: Prestel Publishing.

Jancovich, L. (2017). The participation myth. International Journal of Cultural Policy, 23, 107-121. doi:10.80/10286632.2015.1027698 
Martin, A. (2002). The impact of free entry to museums. Cultural Trends, 12(47), 1-12. doi:10.1080/09548960209390329

Nwonka, C. J., \& Malik, S. (2018). Cultural discourses and practices of institutionalised diversity in the UK film sector: 'Just get something black made'. The Sociological Review, 66(6), 1111-1127.

Owen, H. (2008). Open space technology: A user's guide. San Francisco, CA: Berrett-Koehler Publishers.

Parsons, M. (2008, March 25). Emperor has no clothes in modern art. The Irish Times. Retrieved from www.irishtimes.com/opinion/emperor-has-no-clothes-in-modern-art-1.906646

Price, S., Perry, R., Mantell, O., Trinder, J., \& Pitts, S. (2019). Spontaneity and planning in arts attendance: Insights from qualitative interviews and the audience finder database. Cultural Trends, 28(2-3), 220-238. doi:10.1080/09548963.2019.1617943

Reynolds, N. (2001, December 10). Turner Prize won by man who turns lights off. The Telegraph. Retrieved from www.telegraph.co.uk/news/uknews/1364860/Turner-Prizewon-by-man-who-turns-lights-off.html

Sedghi, A. (2013, May 24). The London art audit: How well are female artists represented? The Guardian. Retrieved from www.theguardian.com/news/datablog/2013/may/24/londonart-audit-female-artists-represented

Taking Part Survey. (2016). Taking part survey: Who participates? - Arts [Data tool]. Retrieved from https://public.tableau.com/profile/taking.part.survey\#!/vizhome/WhoParticipatesArts/Responsesbreakdowns

Taylor, M. R. (2016). Nonparticipation or different styles of participation? Alternative interpretations from taking part. Cultural Trends, 25, 169-181. doi:10.1080/09548963. 2016.1204051

Turino, T. (2008). Music as social life: The politics of participation. Chicago: The University of Chicago Press.

Walmsley, B. A. (2013). Co-creating theatre: Authentic engagement or inter-legitimation? Cultural Trends, 22, 108-118. doi:10.1080/09548963.2013.783176

Alipoor, J. (2018, June 5). The arts world sees working-class people as a problem to be solved. The Guardian. Retrieved from www.theguardian.com/stage/2018/jun/05/artsworking-class-people-britain-theatre

Allen, K., Quinn, J., Hollingworth, S., \& Rose, A. (2013). Becoming employable students and 'ideal' creative workers: Exclusion and inequality in higher education work placements. British Journal of Sociology of Education, 34, 431-452. doi:10.1080/01425692.2012.714249

Arts Council England. (n.d.b). Change makers. Retrieved from www.artscouncil.org.uk/ funding/change-makers

Arts Council England. (2018). Audience development and marketing. Retrieved from www.arts council.org.uk/sites/default/files/download-file/Information_sheets_Audience_development_ marketing_Project_grants_170518.pdf

Baker, T. (2000). Stop re-inventing the wheel: A guide to what we already know about developing audiences for classical music. Retrieved from http://culturehive.co.uk/wp-content/uploads/ 2013/04/Stop-Reinventing-the-Wheel-Guide-to-Classical-Music-Audiences.pdf

Baxter, L. (2010). From luxury to necessity: The changing role of qualitative research in the arts. In D. O'Reilly \& F. Kerrigan (Eds.), Marketing the arts: A fresh approach (pp. 121-140). Abingdon: Routledge.

Brook, O., O’Brien, D., \& Taylor, M. (2018). Panic! It's an arts emergency: Panic! Social class, taste and inequalities in the creative industries. Retrieved from https://createlondon.org/wpcontent/uploads/2018/04/Panic-Social-Class-Taste-and-Inequalities-in-the-CreativeIndustries1.pdf 
Bunting, C., Chan, T. W., Goldthorpe, J., Keaney, E., \& Oskala, A. (2008). From indifference to enthusiasm: Patterns of arts attendance in England. Arts Council England. Retrieved from http://users.ox.ac.uk/ sfos0006/papers/indifferencetoenthusiasm.pdf

Campbell, M. (2018). 'Shit is hard, yo': Young people making a living in the creative industries. International Journal of Cultural Policy, 1-20. doi:10.1080/10286632.2018.1547380

Conor, B., Gill, R., \& Taylor, S. (2015). Gender and creative labour. The Sociological Review, 6, 1-22. doi:10.1111/1467-954X.12237

Cornford, T., \& Whittaker, T. (2017). PIPA best practice research project final report. Retrieved from www.pipacampaign.com/wp-content/uploads/2016/10/PIPA-Best-Practice-ResearchProject-Final-Report-03-11-17-online-2.pdf

Darcy, S., Maxwell, H., Grabowski, S., \& Onyx, J. (2019). Artistic impact: From casual and serious leisure to professional career development in disability arts. Leisure Sciences. Advance online. https://doi.org/10.1080/01490400.2019.1613461

Hadley, S. (2017). European commission final report: Study on audience development How to place audiences at the centre of cultural organisations. Cultural Trends, 26, 275-278. doi:10.1080/09548963.2017.1345739

Holgate, J., \& McKay, S. (2009). Equal opportunities policies: How effective are they in increasing diversity in the audio-visual industries' freelance labour market? Media, Culture \& Society, 31, 151-163. doi:10.1177/0163443708098250

Kawashima, N. (2000). Beyond the division of attenders vs non-attenders: A study into audience development in policy and practice. Centre for cultural policy studies: University of Warwick. Research Papers, 6. Retrieved from https://pdfs.semanticscholar. org/8905/c34d56a38b20b8ea09b8d49bf4d46285abcd.pdf?_ga=2.256192843. 1532160863.1578687181-1736036054.1578687181

Kompatsiaris, P. (2015). Art struggles: Confronting internships and unpaid labour in contemporary art. tripleC: Communication, Capitalism \& Critique: Journal for Global Sustainable Information Society, 13, 554-556. doi:10.31269/triplec.v13i2.613

Lindelof, A. M. (2015). Audience development and its blind spot: A quest for pleasure and play in the discussion of performing arts institutions. International Journal of Cultural Policy, 21, 200-218. doi:10.1080/10286632.2014.891585

McCarthy, K. F., \& Jinnett, K. J. (2001). A new framework for building participation in the arts. Rand Corporation. Retrieved from www.rand.org/content/dam/rand/pubs/monograph_ reports/2005/MR1323.pdf

Miles, A., \& Sullivan, A. (2012). Understanding participation in culture and sport: Mixing methods, reordering knowledges. Cultural Trends, 21, 311-324. doi:10.1080/09548963. 2012.726795

Newsinger, J., \& Eikhof, D. (2020). Explicit and implicit diversity in the UK film and television industries. Journal of British Cinema and Television, 17, 47-69. doi:10.3366/ jbctv. 2020.0507

Nicholson, H., Holdsworth, N., \& Milling, J. (2018). The ecologies of amateur theatre. London: Palgrave Macmillan.

Nwonka, C. J., \& Malik, S. (2018). Cultural discourses and practices of institutionalised diversity in the UK film sector: 'Just get something black made'. The Sociological Review, 66(6), 1111-1127.

Pitts, S. E. (2020). Leisure-time music groups and their localities: Exploring the commercial, educational and reciprocal relationships of amateur music-making. Music and Letters, 101(1), 120-134. https://doi.org/10.1093/ml/gcz044 
Walmsley, B. (2016). From arts marketing to audience enrichment: How digital engagement can deepen and democratize artistic exchange with audiences. Poetics, 58, 66-78. doi:10.1016/j.poetic.2016.07.001

Wiggins, J. (2004). Motivation, ability and opportunity to participate: A reconceptualization of the RAND model of audience development. International Journal of Arts Management, $7(1), 22-33$.

Wilson, N., Gross, J., \& Bull, A. (2017). Towards cultural democracy: Promoting cultural capabilities for everyone. Retrieved from www.kcl.ac.uk/cultural/resources/reports/towardscultural-democracy-2017-kcl.pdf 